\title{
Phytochemical, antioxidant and hepatoprotective effects of Alnus nitida bark in carbon tetrachloride challenged Sprague Dawley rats
}

Moniba Sajid ${ }^{1}$, Muhammad Rashid Khan ${ }^{1 *}$, Naseer Ali Shah², Sayed Afzal Shah³, Hammad Ismail ${ }^{4}$,

Tahira Younis ${ }^{1}$ and Zartash Zahra ${ }^{1}$

\begin{abstract}
Background: Alnus nitida (Spach) Endl. is traditionally used for inflammatory disorders. Diarylheptanoids constituents having diverse therapeutically importance including hepato-protective was reported in $A$. nitida. The aim of this study was to explore the antioxidant and hepato-protective profile of A. nitida stem bark's crude methanol extract (ANM).

Methods: Crude methanol extract of A. nitida stem bark and its derived fractions were assessed for phytochemical classes and in vitro antioxidant profiling by multidimensional assays. Hepato-protective assessment of ANM was investigated on rats, which were made hepatotoxic using carbon tetrachloride $\left(\mathrm{CCl}_{4}\right)$. Additionally HPLC-DAD analysis of ANM, and its derived ethyl acetate and aqueous fraction was carried out to determine the presence of active constituents.

Results: Qualitative analysis of crude extract-and its fractions depicted the presence of terpenoids, saponins, coumarins, phenols and flavonoids. Maximum quantity of total phenolic content (TPC) and total flavonoid content (TFC) was recorded in ANM and its derived fractions; n-hexane (ANH), chloroform (ANC), ethyl acetate (ANE) and the residual aqueous (ANA). ANM exhibited the best total antioxidant capacity, total reducing power, and scavenging of DPPH and OH radicals. ANE and ANA exhibited strong scavenging potential for iron chelation, nitric oxide and $\beta$-carotene bleaching assay. ANM treatment converse the activities of serum-marker enzymes and lipid profile, altered by $\mathrm{CCl}_{4}$ treatment in rat. $\mathrm{CCl}_{4}$ induced hepatic-cirrhosis in rat resulted in decrease of antioxidant enzyme activities such as catalase, peroxidase, superoxide dismutase, glutathione peroxidase, glutathione-S-transferase and glutathione reductase-which were restored towards the normal level with ANM. Similarly diminished level of reduced glutathione while enhanced level of lipid peroxides, hydrogen peroxide and nitrite in liver of cirrhotic rats was normalized by treatment of ANM. The histopathological studies of liver tissues also represented that ANM possessed the hepato-protective activity. HPLC-DAD analysis against eight known standards confirmed the presence of gallic acid, catechin and rutin in ANM and in ANA while in ANE gallic acid was only detected.
\end{abstract}

Conclusion: Based on the results of antioxidants, restoration of various antioxidant enzymes and histopathological studies, the recent study concludes that antioxidant potential of $A$. nitida bark might protect the liver damages.

Keywords: Alnus nitida, Antioxidant, Hepatoprotective, HPLC, Phenolics, Flavonoids

\footnotetext{
* Correspondence: mrkhanqau@yahoo.com

'Department of Biochemistry, Faculty of Biological Sciences, Quaid-i-Azam

University, Islamabad, Pakistan

Full list of author information is available at the end of the article
} 


\section{Background}

Plants are currently recognized as an opulent source of antioxidant compounds (e.g., flavonoids, simple phenolics, stilbenes, anthocyanins), which are used chiefly in food industry [1,2]. It is deliberated that utilization of plant-based antioxidants could be associated with reduced risk of occurrence of numerous human diseases narrated to the oxidative stress [3].

Antioxidants have long been known to protect the biological system through inhibition or deterrence of oxidation stress tempted by reactive oxygen substances produced during usual metabolic activities or environmental factors [4]. Thus, the oxidative stress induced damages of DNA, lipids and proteins may cause various diseases [5].

Liver is an imperious organ in human body [6]. Liver is subordinated with vital functions such as it sustains and normalizes the homeostasis in body. It plays an astounding role in human body as it mediates several biochemical pathways such as body defense against diseases, energy production, and for source of nutrition [7]. Oxidative-stress plays a foremost role in the progress of liver diseases. The liver injury is recruited by the various noxious agents produced by chemicals, viruses or by their bio-activation to chemically reactive metabolites. These metabolites can be free radicals, which either prompts an immune response or directly affects the biochemistry of the cells by cooperating with cellular macromolecules. Even after the encroachment in modern system of medicine, there is deficiency of a trustworthy synthetic liver defensive drug. Hence, natural extracts /products from medicinal plants are considered to be effective for the management of liver disorders [8].

Experimental models of hepatotoxicity can be produced by alcohol, paracetamol, $\mathrm{CCl}_{4}$ etc. $\mathrm{CCl}_{4}$ is the extreme potent hepatotoxic agent practiced for experimental generation of liver fibrosis [9]. $\mathrm{CCl}_{4}$ is metabolized by cytochrome $\mathrm{P} 4502 \mathrm{E} 1$ to the trichloromethyl radical $\left({ }^{\circ} \mathrm{OCCl}_{3}\right)$ and peroxy trichloromethyl radical $\left({ }^{\circ} \mathrm{OOCCl}{ }_{3}\right)$. It has been reported that one of the cause of $\mathrm{CCl}_{4}$-induced liver injury is lipid peroxidation, which is prompted and accelerated by free radical derivatives of $\mathrm{CCl}_{4}[10]$.

Alnus nitida (spach) Endl belongs to family Betulaceae, ordinarily known as Sharoliin Punjab and Seril iniKashmir, is a deciduousiwoody tree, distributed in westerniHimalayas from Yamuna westwards to Kashmir [11, 12]. Alnus species contained diarylheptanoids; a group of natural compounds having 1,7-diphenylheptane skeleton imparting diverse therapeutic effects. About 400 diarylheptanoids [13] have been isolated from different species of Alnus showing various pharmacological activities; antiinflammatory [14, 15], anti-influenza [16], and hepatoprotective [17]. Various isolates or the derivatives of diarylheptanoids from $A$. japonica showed antioxidant effects during in vitro studies $[18,19]$. The diarylheptanoids were also isolated from other medicinal sources such as Zingiber, Curcuma, Alpinia and Myrica. Two diarylheptanoids nitidoneiA and nitidone $B$ have been reported from A. nitida found in Northern areas of Pakistan [20]. Stem bark of $A$. nitida is pounded and paste is applied externally by the local communities as a remedy for swelling, injuries and pain. Its decoction is also used for internal injuries. Root or stem bark of $A$. nitida is blended with Urtica dioca, Rumex nepalensis, Zingiber officinale and paste is used in bone fractures [21]. Extract of A. japonica have shown promising effects in alleviating the acetaminophen induced hepatic injury in rat [22]. Hence, the current study was designed to scrutinize the preliminary phytochemical composition, as well as to estimate the antioxidant and hepato-protective activity of methanol extract of $A$. nitida stem bark against $\mathrm{CCl}_{4}$ induced hepatotoxicity in rat. The crude extract and its derived fractions; ethyl acetate and residual aqueous fractions exhibited significant antioxidant activity were subjected to HPLC-DAD analysis for the presence of polyphenolic constituents.

\section{Methods}

\section{Reagents and chemicals}

Analytical grade chemicals used: sodium carbonate, sodium nitrite, dosium dihydrogen, hydrogen peroxide, ferrous chloride, 2-deoxyribose, potassium ferricyanide, sulphuric acid were bought from Merck. 1,1-diphenyl-2-picryl-hydrazyl, potassium persulphate, 2-ethylbenzothiazoline sulfonic acid, rutin, nitro blue, Folin-Ciocalteu's reagent, phenazine methosulphate, trichloroacetic-acid and tetrazolium were obtained from Sigma Chemicals Co., St. Louis USA. Oxidized glutathione (GSSG), (DTNB), glutathione (GSH),1,2-dithio-bis-nitroLbenzoic-acid (DTNB), glucose6-phosphate, thiobarbituric acid (TBA), trichloroacetic acid (TCA), sodium tungstate, perchloric acid (PCA), 2,6dichlorophenolindophenol, reduced glutathione (GSH), sodium hydroxide, reduced nicotinamide adenine dinucleotide phosphate (NADPH), sodium tungstate, glucose-6phosphate, rutin, catechin, gallic acid, caffeic acid, apigenin, quercetin, myricetin, and kampferol were bought from Sigma Chemicals Co., USA were used.

\section{Plant sampling}

Alnus nitida stem bark was collected from Charbagh town of district Swat, Pakistan during March-April (2015.) The spot of collection was at $34.842727^{\circ}$ north latitude and $72.431089^{\circ}$ east longitude; at an elevation of $1000 \mathrm{~m}$. Flora of Pakistan [23] was used for the identification of plant and further authenticated by Dr. Sumaira Sahreen, Associate Curator, Pakistan Museum of National History. The authenticated specimen (127963) was held at Pakistan Museum of National History. 


\section{Extract preparation}

At room-temperature for 2 weeks the bark of A. nitida was air-dried under-shade-and with the help of Willy Mill granulated to 80 -mesh size. Bark powder $(5 \mathrm{~kg})$ was drenched in-15 L of $95 \%$-methanol and reprises-the soaking thrice-and filtered the-extract-with WhatmanLNo.L1 filter paper. Rotary evaporator was utilized to dry the filtrate (ANM) under vacuum. Partial purification or separation was done by solvent-solvent extraction in escalating polarity. In the distilled water the extract was suspended and the solvents i.e., n-hexane (ANH), chloroform (ANC) and ethyl acetate (ANE) were used in augmentation order of polarization and as an aqueous extract residual (ANA) was used. Rotary evaporator was used for the evaporation of solvents of all the fractions, and then preserved at $4{ }^{\circ} \mathrm{C}$.

\section{Phytochemical analysis}

Different qualitative tests were employed to identify the phytochemical classes present in the crude methanol extract and various fractions of the stem bark of $A$. nitida.

\section{Assessment of phenols}

For the presence of phenols previously reported methodology was followed [24]. Each sample (1 mg) was suspended in $2 \mathrm{ml}$ of distilled water containing $10 \%$ ferric chloride. The confirmation sign for the presence of phenol was the development of blue or green color.

\section{Assessment of flavonoids}

In order to investigate the presence of flavonoids in each sample Trease and Evans protocol [24] was employed. Briefly, $1 \mathrm{mg}$ of every sample was allowed to react with $1 \mathrm{ml}$ of $2 \mathrm{~N}$ sodium hydroxide. Appearance of yellow color was considered as the confirmation signal of flavonoid presence.

\section{Assessment of coumarins}

An amount of $1 \mathrm{mg}$ of each sample was blended with $1 \mathrm{ml}$ of $10 \%$ sodium hydroxide. Appearance of yellow color in the test tube was the evidence of coumarins presence in the sample [24].

\section{Assessment of saponins}

Each sample $(2 \mathrm{mg})$ was suspended in $2 \mathrm{ml}$ of distilled water and vigorously mixed. The formation of a soapy layer of almost $1-2 \mathrm{~cm}$ was the indication of saponins presence [24].

\section{Assessment of tannins}

The confirmative signal of tannins presence was the development of dim blue or greenish dark shading on the mixing of $1 \mathrm{mg}$ of every sample and $3 \mathrm{ml}$ of $5 \%$ ferric chloride [24].

\section{Assessment of terpenoids}

Each sample $0.5 \mathrm{mg}$ was mixed with $3 \mathrm{ml}$ of chloroform and $3 \mathrm{ml}$ of concentrated-sulphuric acid. The appearance of red brown colored layer in the middle of two layers confirmed the existence of terpenoids [24].

\section{Assessment of anthraquinones}

Development of red color was considered as indication for the presence of anthraquinones after mixing of $1 \mathrm{mg}$ of each sample with $2 \mathrm{ml}$ of diluted $2 \%$ hydrochloric acid [24].

\section{Assessment of anthocyanins and betacyanins}

Each sample $(1 \mathrm{mg})$ was boiled for $10 \mathrm{~min}$ in $2 \mathrm{ml}$ of $1 \mathrm{~N}$ sodium hydroxide. Formation of bluish green color was the sign of anthocyanin and yellow color formation of betacyanin presence [25].

\section{Assessment of alkaloids}

An amount of $2 \mathrm{mg}$ of each sample was mixed with concentrated sulphuric acid. The reaction mixture was allowed to react with Mayer's reagent. Appearance of green color or formation of white precipitates was the symbol of alkaloid presence [25].

\section{Quantitative analysis}

Total phenolic as well as flavonoid contents were quantified by the following narrated procedures.

\section{Total phenolic contents (TPC)}

Spectrophotometric analysis was performed for the analysis of total phenolic content [26]. Each sample (1 $\mathrm{mg} / \mathrm{ml}$ ) was briefly blended with $9 \mathrm{ml}$ of distilled water and $2 \mathrm{ml}$ of Folin Ciocalteu reagent. The acquired mixture was mixed vigorously for $10 \mathrm{~min}$ and $10 \mathrm{ml}$ ofL $7 \% \mathrm{Na}_{2} \mathrm{CO}_{3}$ was further mixed in to the mixture. Mixture's final volume was raised to $25 \mathrm{ml}$ by adding distilled water and then placed into the incubator at room temperature for $60 \mathrm{~min}$. Absorbance of the reaction mixture was measured at wavelength of $750 \mathrm{~nm}$ in triplicates for each sample. Gallic-acid was kept as standard, the estimation of TPC was done as mg of gallic acid equivalents (GAE) per gram of dryLextract/fraction.

\section{Total flavonoid content (TFC)}

For the TFC evaluation in the test samples, $0.3 \mathrm{ml}$ of each sample was mixed with $0.25 \mathrm{M} \mathrm{NaNO}{ }_{2}(0.25 \mathrm{ml})$ -followed by the addition of $0.1-\mathrm{ml}$ of $0.3 \mathrm{MLAlCl}_{3} \cdot 6 \mathrm{H}_{2} \mathrm{O}$, and $3.4 \mathrm{ml}$ of $-30 \%$ methanol [27]. After 5 min interval $2 \mathrm{ml}$ aliquot of $1 \mathrm{M} \mathrm{NaOH}$ was added to it. At the wavelength of $506 \mathrm{~nm}$ the absorbance of reaction amalgam was measured against the reagent blank. Content of total flavonoid as-mg rutinLequivalentsLper gram of dryLextract/ 
fraction was assessed by employing the calibration-curve of rutin.

\section{High performance liquid chromatography (HPLC-DAD) analysis}

HPLC analysis of ANM and selected plant fractions (ANE and ANA) was performed using HPLC-DAD (Agilent 1200, Germany) equipped with Zorbex RXC8 (Agilent, USA) analytical column with $5 \mu \mathrm{m}$ particle size and $25 \mathrm{ml}$ capacity using previously reported method [28]. Each sample was diluted with HPLC grade methanol. Mobile phase was consisted of eluent A, (acetonitrile- methanol-water- acetic acid-/5: 10: 85: 1)-and eluent B (acetonitrile-methanol-acetic acid/40: 60:-1). The gradient (A: B) utilized was the following: 0-20 min (0 to $50 \% \mathrm{~B}$ ), 21-25 $\mathrm{min}$ (50 to $100 \% \mathrm{~B}$ ), 26-30 min $(100 \% \mathrm{~B})$ and $31-40(100$ to $0 \% \mathrm{~B})$ at flow rate ofL1 $\mathrm{ml} / \mathrm{min}$. The standards and samples were prepared in HPLC grade methanol (1 $\mathrm{mg} / \mathrm{ml})$, filtered through $0.45 \mu \mathrm{m}$-membrane filter andL20 $\mu \mathrm{l}$ was injected for the analysis. Among the standards rutin was investigated at $257 \mathrm{~nm}$, catechin and gallic acid at $279 \mathrm{~nm}$, caffeic acid and apigenin at $325 \mathrm{~nm}$ while quercetin, myricetin and kampferol were analyzed atL368 nm [29]. The analysis was performed in triplicate and the column was reconditioned for 10 min after each run. Quantification was done by the integration of the peak by using the external standard method.

\section{In vitro antioxidant assays}

The in vitro antioxidant assays were carried out by preparing the plant samples $(1 \mathrm{mg} / \mathrm{ml})$ in $95 \%$ methanol and then making its serial dilutions. The specific protocol was followed for finding specific scavenging activities of the plant samples.

\section{DPPHL (1, 1-diphenyl-2-picryl-hydrazyl) radical scavenging assay}

DPPH scavenging capacity of injurious impacts of free radicals was dictated by following the methodology reported previously [30]. A volume of $100 \mathrm{ml}$ of methanol was used as solvent for $24 \mathrm{mg}$ of DPPH and the stock was kept at $20{ }^{\circ} \mathrm{C}$ temperature for further utilization. The dilutions of pre-made DPPH stock solutions were prepared in methanol by optimizing absorbance of DPPH was at $0.908( \pm 0.02)$ at wavelength $517 \mathrm{~nm}$. Different concentrations $(25-250 \mu \mathrm{g} / \mathrm{ml})$ of $100 \mathrm{ml}$ of plant samples were mixed with dilution of $3 \mathrm{ml}$ of DPPH. The tubes were thoroughly mixed and placed for $15 \mathrm{~min}$ in incubator at room temperature. Absorbance of the reaction mixture was measured at wavelength of $517 \mathrm{~nm}$. Ascorbic acid was utilized as standard to compare the antioxidant activity. Potential as an antioxidant was determined by using Eq. 1:

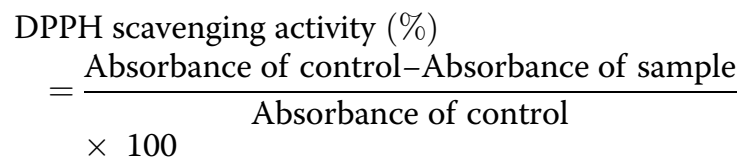

\section{Nitric oxide scavenging assay}

Nitric oxide scavenging activity of ANM and its derived fractions was estimated by using Griess reagent as the main ingredient [31]. DMSO was used as a solvent for the preparation of plant sample and for serial dilutions. For the development of Griess reagent, equimolar amount of $0.1 \%$ napthylenediamine in distilled water and $1 \%$ of sulphanilamide in $5 \%$ phosphoric acid was added. An aliquot of $0.2 \mathrm{ml}$ of sample was mixed with $0.2 \mathrm{ml}$ of sodium-nitroprusside $(10 \mathrm{mM})$ being formulated in saline phosphate buffer followed by addition of $2 \mathrm{ml}$ aliquot of the Griess reagent to the reaction blend. For $3 \mathrm{~h}$ the reaction blend was incubated at room temperature and the absorbance was measured at the wavelength of $546 \mathrm{~nm}$ spectrophotometrically utilizing ascorbate as a positive control. For assessing the percentage inhibition of nitric oxide radical formation equation 1 was used.

\section{Hydroxyl radical scavenging assay}

For measuring the scavenging ability of methanol extract and its fractions of A.nitida, Halliwell et al. [32] methodology was followed. DMSO was used as a solvent for the preparation of plant sample and for serial dilutions. As per the procedure, $500 \mu \mathrm{l}$ of $2.8 \mathrm{mM}$ ) 2-deoxyribose was prepared in $50 \mathrm{mM}$ phosphate buffer and $\mathrm{pH}$ was maintained at 7.4. The reaction cocktail was made by addition of $0.1 \mathrm{ml}$ of $0.1 \mathrm{M}$ EDTA, $0.2 \mathrm{ml}$ of ferric chloride $(100 \mathrm{mM})$ and $0.2 \mathrm{ml}$ of $200 \mathrm{mM} \mathrm{H} \mathrm{H}_{2} \mathrm{O}_{2}$ and $0.1 \mathrm{ml}$ of plant sample. To begin the reaction $0.1 \mathrm{ml}$ of ascorbic acid $(300 \mathrm{mM})$ was added and for $1 \mathrm{~h}$ placed in incubator at $37{ }^{\circ} \mathrm{C}$. After that $2.9 \%$-trichloroacetic acid (2 ml) and $1 \% \mathrm{w} / \mathrm{v}$ thiobarbituric acid $(2 \mathrm{ml})$ prepared in $50 \mathrm{mM} \mathrm{NaOH}$ were further added to the reaction cocktail and for 15-min the whole mixture was heated in water bath. The absorbance was measured at wavelength of $532 \mathrm{~nm}$ once the mixture temperature falls to room temperature. For the analysis of hydroxyl radical scavenging activity Eq. 2 was applied:

$$
\begin{aligned}
& \text { Superoxide scavenging activity }(\%) \\
& =\left(1-\frac{\text { Absorbance of sample }}{\text { Absorbance of control }}\right) \times 100
\end{aligned}
$$

\section{$\beta$-Carotene bleaching assay}

The ability of $A$. nitida methanol extract and its fractions for $\beta$-carotene bleaching was determined by using the scheme of Dapkevicius et al. [33]. DMSO was used as a solvent for the preparation of plant sample and for 
serial dilutions. In $10 \mathrm{ml}$ of chloroform $2 \mathrm{mg}$ of $\beta$ carotene was added and subsequently added $100 \mathrm{mg}$ of Tween 80Land $20 \mathrm{mg}$ of linoleic acid. Once the chloroform evaporated form the reaction blend, $100 \mathrm{ml}$ ofdistilled water was added, and vivaciously vortexed to achieve a uniform emulsion of $\beta$-carotene linoleate. In freshly prepared $250 \mu \mathrm{l}$ of emulsion, $30 \mu \mathrm{l}$ of plant sample was added and optical density was measured at wavelength of $470 \mathrm{~nm}$ at $0 \mathrm{~h}$. Finally the absorbance was measured and recorded after keeping the reaction mixture at $40{ }^{\circ} \mathrm{C}$ for $1 \mathrm{~h}$. Catechin served as standard in this assay and \% inhibition of $\beta$-carotene was determined by Eq. 3:

$$
\text { Percentage inhibition }=\frac{\text { Absorbance after } 2 \mathrm{~h}}{\text { Initial absorbance }}
$$

\section{Chelating power assay}

The iron (II) binding capability at multiple sites confers the antioxidant potential of plant samples [34]. Methanol was used as a solvent for the preparation of plant sample and for serial dilutions. A volume of $200 \mu \mathrm{l}$ of each dilution was mixed with $900 \mu \mathrm{l}$ of methanol and $100 \mu \mathrm{l} \mathrm{FeCl} 2.2 \mathrm{H}_{2} \mathrm{O}(2.5 \mathrm{mM})$ and incubated for $5 \mathrm{~min}$. To trigger the reaction $800 \mu \mathrm{l}$ of ferrozine $(6.0 \mathrm{mM})$ was introduced and afterL15 min of incubation the optical density was recorded at $562 \mathrm{~nm}$ using EDTA as standard in comparison. For the evaluation of chelating power following Eq. 4 was employed:

$$
\begin{aligned}
& \text { Chelating effect } \% \\
& =\quad \begin{aligned}
& {\left[\begin{array}{c}
\text { Absorbance of control } \\
\end{array}\right.} \\
& - \text { Absorbance of the sample } / \\
\times & \text { Absorbance of control }]
\end{aligned}
\end{aligned}
$$

\section{Reducing power assay}

DMSO was used as a solvent for the preparation of plant sample and for serial dilutions. Briefly, $4 \mathrm{ml}$ of plant extract was taken and mixed with $4 \mathrm{ml}$ of $0.3 \mathrm{M}$ phosphate buffer ( $\mathrm{pH} 6.8)$ and $4 \mathrm{ml}$ of potassium ferricyanide $(10 \mathrm{mg} / \mathrm{l})$ and the reaction cocktail was placed in the incubator for $20 \mathrm{~min}$ at $80{ }^{\circ} \mathrm{C}$ for $10 \mathrm{~min}$. After addition of $4 \mathrm{ml}$ of trichloroacetic acid $(200 \mathrm{mg} / \mathrm{l})$ in the reaction cocktail, $2 \mathrm{ml}$ was of it was diluted with $4 \mathrm{ml}$ of distilled water and $0.6 \mathrm{ml}$ of $\mathrm{FeCl}_{3}(0.2 \%)$. Optical density of the reaction mixture was taken at $700 \mathrm{~nm}$ after $10 \mathrm{~min}$ of incubation. Gallic acid was appropriated as a standard [35].

\section{Phosphomolybedenum assay}

The methodology of Prieto et al. [36] was used to assess the antioxidant capabilities of the plant samples. DMSO was used as a solvent for the preparation of plant sample and for serial dilutions. Accordingly, $0.2 \mathrm{ml}$ of the plant sample was mixed with $2 \mathrm{ml}$ of the reagent solution (prepared by adding $28 \mathrm{mM} \mathrm{Na}_{3} \mathrm{PO}_{4}$ and $0.6 \mathrm{M} \mathrm{H}_{2} \mathrm{SO}_{4}$ with that of $4 \mathrm{mM}$ ammonium molybdate). After incubation at $90{ }^{\circ} \mathrm{C}$ in a water bath for $80 \mathrm{~min}$ the reaction mixture was cooled down at room temperature and optical density was recorded at $765 \mathrm{~nm}$.

\section{In vivo $\mathrm{CCl}_{4}$ induced hepatotoxicity in rats Animals}

Six weeks old (180-200 g) Sprague-Dawley-male rats were acquired from the Animal House situated at the Quaid-i-Azam University Islamabad, Pakistan. The animals were maintained at $24 \pm 3{ }^{\circ} \mathrm{C}$ with a $12 \mathrm{~h}$ dark/light cycle at Primate Facility of the Quaid-i-Azam University Islamabad, Pakistan. The animals were bred with basal diet with water ad libitum and were sustained in standard laboratory conditions. The basal diet was composed of $20 \%$ protein (casein), $10 \%$ sucrose, $5 \%$ corn oil, $2 \%$ choline chloride, $1 \%$ vitamin mixture, $3.5 \%$ salt mixture and $5 \%$ fibers (cellulose). The remainder was corn starch up to $100 \%$. Prior to the research propagation ethical approval (Bch\#0275) was obtained from Ethics Committee Quaid-i-Azam University Islamabad. Experiments on animals were performed in accordance with the guidelines of the institute of animal ethical committee, NIH, Islamabad.

\section{Acute toxicity test}

Six week old Male Sprague Dawley rats were kept in fasting conditions for overnight with just water availability. Three animals were intra-gastrically administered with dose-of $50 \mathrm{mg} / \mathrm{kg}$ bw and were monitored for mortality rate for 2 weeks. DMSO was used as a solvent for the preparation of extract/fraction samples. No initial progression of toxicity was observed, but the methodology was subsequently followed with augmented amount of doses i.e., 100,-200, 400, 1000, 2000, 3000 and $4000 \mathrm{mg} / \mathrm{kg}$ bw of the maximum dose of the extract. Three animals were used for each treatment. Mortality was not noticed at the highest dose of $4000 \mathrm{mg} / \mathrm{kg}$, thus 200 and $400 \mathrm{mg} / \mathrm{kg}$ bw doses were selected for the evaluation of hepatoprotective propagation activities [37].

\section{Experimental design}

Eight groups (each having 7 rats) of Sprague-Dawley male-rats were made to contemplate the hepatoprotective effects of ANM. Group I was taken as a control and remained untreated. Olive oil and DMSO $(1: 1 ; \mathrm{v} / \mathrm{v})$ at a dose of $1 \mathrm{ml} / \mathrm{kg}$ bw was administrated to the Group II orally. Group III was intraperitoneally administered with $\mathrm{CCl}_{4}\left(1 \mathrm{ml} / \mathrm{kg}\right.$ bw; $\mathrm{CCl}_{4}$ :Olive oil; $\left.2: 8 \mathrm{v} / \mathrm{v}\right)$. An amount of $50 \mathrm{mg} / \mathrm{kg}$ bw of silymarin (in DMSO; w/v) as a reference chemical was given to Group IV after $24 \mathrm{~h}$ of $\mathrm{CCl}_{4}$ 
treatment. Group V and VI were initially treated with $\mathrm{CCl}_{4}$ and then after $24 \mathrm{~h}$, they were orally administered with 200 and $400 \mathrm{Lmg} / \mathrm{kg}$ bw (in DMSO) of ANM. Animals of Groups VII and VIII received only ANM in DMSO at a dose-of-200 and $400 \mathrm{mg} / \mathrm{kg}$ bw, respectively. Once the experiment was accomplished, weight of the animals was recorded. Then the animals were euthanized after ether anesthesia. Blood was collected from heart (atrium), immediately removed the liver and transferred to the chilled saline solution and weighted. One liver portion was prepared for-histopathalogical studies, while the second portion was preserved in liquid nitrogen-and stowed at $-80{ }^{\circ} \mathrm{C}$ for-added enzymatic and DNA damage investigation.

\section{Biochemical studies of serum}

Different liver marker enzymes were used to perform the liver function tests such as alanine transaminase (ALT), aspartate transaminase (AST), alkaline phosphatase (ALP) and bilirubin in serum was evaluated by standard procedure of AMP Diagnostic kits (Stattogger Strasse 31b 8045 Graz, Austria). Serum level of high density lipoproteins (HDL), low density lipoproteins (LDL), total cholesterol and triglycerides were estimated by following the procedures available on the kits.

\section{Biochemical studies of liver}

Small portion of liver was homogenized by the use of homogenizer. Volume of homogenate was noted and accordingly the $10 \times$ homogenate was prepared by mixing with EDTA $(1 \mathrm{mM})$ and phosphate buffer $(100 \mathrm{mM})$. The homogenate was placed for $20 \mathrm{~min}$ at $4{ }^{\circ} \mathrm{C}$ and then centrifuged at $12,000 \times \mathrm{g}$ in order to assemble the supernatant. The protein concentration in theLsupernatant was evaluated-according to the method of Lowry et al. [38] using BSA as standard.

\section{Catalase assay (CAT)}

On the basis of decomposition of hydrogen peroxide CAT actions were analyzed by following the method of Chance and Maehly [39]. In short, $2.5 \mathrm{ml}$ of phosphate buffer (50 mM; pH 6.6) as a solvent for of the supernatant (0.1 ml) and $0.4 \mathrm{ml}$ of $\mathrm{H}_{2} \mathrm{O}_{2}$ (5.9 mM; $\mathrm{pH} 6.0$ ), change in absorbance was noted for one minute at wavelength of $240 \mathrm{~nm}$ in aspectrophotometer.-A change of 0.01 in-absorbance for oneminute was taken as one unit of CAT activity.

\section{Peroxidase assay-(POD)}

Activities of POD were evaluated based on guaiacol peroxidation [39]. To find the POD activity of supernatant the reaction mixture was prepared by adding $0.3 \mathrm{ml}$ of guaiacol $(20 \mathrm{mM}), 0.6 \mathrm{ml}$ of $\mathrm{H}_{2} \mathrm{O}_{2} \mathrm{l}(40 \mathrm{mM})$, and $0.2 \mathrm{ml}$ of the supernatant to $3.5 \mathrm{ml}$ of phosphate buffer (50 mM, pH 5.6) serially. Change in absorbance of the reaction solution at $470 \mathrm{~nm}$ was observed for one minute. One unit of POD activity was defined as an absorbance-change-of 0.01 of the-solution-per minute.

\section{Superoxide dismutase assay-(SOD)}

For the assessment of hepatic SOD activity, to the reaction blend after the centrifugation $(2500 \times \mathrm{g}$ for $20 \mathrm{~min}$ followed by $10,000 \times \mathrm{g}$ for $20 \mathrm{~min}) 300 \mu \mathrm{l}$ of supernatant along with $1.4 \mathrm{ml}$ of sodium-pyrophosphate buffer $(0.053 \mathrm{mM}$; pH 7.3), $0.2 \mathrm{ml}$ of phenazinemethosulphateL $(188 \mu \mathrm{M})$ were added to the reaction mixture. To initiate the reaction $0.4 \mathrm{ml}$ of $\mathrm{NADH}$ $(785 \mu \mathrm{M})$ was added and-then stopped after $3 \mathrm{~min}$ by adding $2 \mathrm{ml}$ of glacial acetic acid. The color intensity was measured at wavelength of $560 \mathrm{~nm}$ [40].

\section{Glutathione-S-transferase assay (GST)}

The principle of this methodology is based on the interaction of GSH andL1-chloro-2,4-dinitrobenzeneL(CDNB)Land the subsequent conjugate made is measured with a spectrophotometer [41]. Shortly, $1.575 \mathrm{ml}$ of phosphate buffer (0.2 M, pH 6.8), $0.3 \mathrm{ml}$ of GSH (2LmM), $0.028 \mathrm{ml}$ of 1-chloro-2,4-dinitrobenzeneL(CDNB; 1LmM) were blended followed by $1.2 \mathrm{ml}$ of supernatant. GST activity was estimated by noting-the change in absorbance at wavelength of $340 \mathrm{~nm}$ with a molar extinction-coefficient of $8.6 \times 10^{3} \mathrm{M}^{-1} \mathrm{~cm}^{-1}$.

\section{Glutathione reductase assay (GSR)}

GSR analysis was done by following the method of Carlberg and Mannervik [42]. Supernatant samples $(0.2 \mathrm{ml})$ were amalgamated with $0.1 \mathrm{ml}$ of EDTA $(0.5 \mathrm{mM})$, $1.68 \mathrm{ml}$ of phosphate buffer,- $0.04 \mathrm{ml}$ of oxidized glutathione $(1 \mathrm{mM})$, and $0.1 \mathrm{ml}$ of NADPH $(0.1 \mathrm{mM})$. The OD was measured atL340 $\mathrm{nm}$ after blending. GST activity was estimated as nM NADPH oxidized/min/mg protein, using a molar extinction coefficient of $8.22 \times 10^{3} \mathrm{M}^{-1} \mathrm{~cm}^{-1}$.

\section{Glutathione peroxidase-assay (GSH-Px)}

The activity of glutathione peroxidase was assayed as described earlier [43]. Hepatic-supernatant $(1.2 \mathrm{ml})$ of every rat was mixed with $1.46 \mathrm{ml}$ phosphate buffer (0.2 M; pH 7.9), $0.1 \mathrm{ml}$ of EDTA $(2 \mathrm{mM}), 0.2 \mathrm{ml}$ of sodium azide $(2 \mathrm{mM}), 0.06 \mathrm{ml}$ of glutathione reductase ( $1 \mathrm{IU} / \mathrm{ml}), 0.08 \mathrm{ml}$ of GSH $(2 \mathrm{LmM}), 0.2 \mathrm{ml}$ of NADPH (0.4 mM), $\mathrm{L} 0.01 \mathrm{ml}$ of $\mathrm{H}_{2} \mathrm{O}_{2}(0.25 \mathrm{mM})$. The absorbance was noted at $340 \mathrm{~nm}$, and GSH-Px activity was assessed by using a molar extinction coefficient of $6.23 \times 10^{3} \mathrm{M}$ $\mathrm{cm}^{-1}$.

\section{Reduced glutathione assay (GSH)}

The concentration of reduced glutathione was assessed by spectrophotometric technique [44]. The basis of this method-is based on the breakdown-of 1,2-dithio-bis 
nitro-benzoic acid (DTNB) by sulfosalicylic acid, as a result yellow-color is produced. The yellow color produced was read immediately at $412 \mathrm{~nm}$ on aspectrophotometer and was expressed as $\mu \mathrm{M} \mathrm{GSH} / g$ tissue.

\section{Estimation of lipid-peroxidation assay (TBARS)}

The analysis of lipid peroxides as thiobarbituric acid reactive substances (TBARS) was done by following protocol of Iqbal and Wright [45]. Shortly after the ascorbic acid and ferric chloride were mixed with the supernatant it was put in a shaking water bath at $37{ }^{\circ} \mathrm{C}$ for $1 \mathrm{~h}$, after that trichloroacetic acid was added. $2.0 \mathrm{ml}$ $0.69 \%$ thiobarbituric acid was added and all the tubes were placed in a water bath to boil for $10 \mathrm{~min}$, and then transferred to crushed ice bath before centrifuging at $2500 \times \mathrm{g}$ for $15 \mathrm{~min}$. The quantity of TBARS manufactured in each of the samples was evaluated by measuring the OD of the supernatant atI535 $\mathrm{nm}$ against a reagent blank. The outcomes were expressed as nM TBARS/ $\mathrm{min} / \mathrm{mg}$ tissue-at $37{ }^{\circ} \mathrm{C}$ using a molar extinction coefficient of $2.58 \times \mathrm{M}^{-1} \mathrm{~cm}^{-1}$.

\section{Hydrogen peroxide assay $\left(\mathrm{H}_{2} \mathrm{O}_{2}\right)$}

Oxidation of phenol red in the presence of $\mathrm{H} 2 \mathrm{O} 2$ mediated horseradish peroxidase was done to assay hydrogen peroxide $\left(\mathrm{H}_{2} \mathrm{O}_{2}\right)$ [46]. Horse radish peroxidase (8.5 units), phenol red $(0.29 \mathrm{nM})$, dextrose $(6.6 \mathrm{nM})$ and phosphate buffer (0.04 M; pH 8.0), comprising solution was used for the suspension of homogenate sample $(3.0 \mathrm{ml})$ and incubation was done at $37^{\circ} \mathrm{C}$ for $60 \mathrm{~min}$. A volume of $0.01 \mathrm{ml}$ of $\mathrm{NaOH}(1 \mathrm{~N})$ was mixed following centrifugation at $800 \times \mathrm{g}$ for $5 \mathrm{~min}$. Supernatant was checked for absorbance at $615 \mathrm{~nm}$ against a reagent blank. $\mathrm{H}_{2} \mathrm{O}_{2} / \mathrm{min} / \mathrm{mg}$ tissue-based concentration was shown on the basis of $\mathrm{H}_{2} \mathrm{O}_{2}$ oxidized phenol red of standard curve.

\section{Nitrite assay}

Equal quantity i.e. $100 \mu \mathrm{l}$ each of both $5 \% \mathrm{ZnSO}_{4}$ and $0.3 \mathrm{M} \mathrm{NaOH}$ was used to remove the proteins of tissue samples $(100 \mathrm{mg})$, which were then centrifuged at $6400 \mathrm{~g}$ for 15-20 min. The supernatant was collected by centrifugation at $6400 \times \mathrm{g}$ for $20 \mathrm{~min}$. To the cuvette Griess reagent $(1.0 \mathrm{ml})$ was added, and the spectrophotometer was blanked at wavelength of $540 \mathrm{~nm}$, then the supernatant was added to the cuvette having Griess reagent. Nitrite concentration was computed using a standard curve for sodium nitrite [47].

\section{Tissue protein estimation}

The method of Lowry et al. [38] was used to determine the total amount of soluble protein in tissue homogenate. To the tissue homogenate $200 \mu \mathrm{l}$ of $1.1 \mathrm{M}$ potassium phosphate buffer-( $\mathrm{pH} 8.0)$ was added to dilute the tissue sample. A volume of $1 \mathrm{ml}$ of alkaline copper-solution was added to-this blend, and placed at room temperature. After incubation for $20 \mathrm{~min}, 200 \mu \mathrm{l}$ of Folin-Ciocalteu phenol reagent was added. Reaction tubes containing the test mixtures were then vortexed and incubated again atL37 ${ }^{\circ} \mathrm{C}$ for $20 \mathrm{~min}$. At $650 \mathrm{~nm}$ optical density was measured spectrophotometrically. Total soluble proteins of the tissue samples-were then detected using standard curve of bovine serum-albumin.

\section{Histopathological studies}

Histopathological examination was performed for the hepatic injuries. Samples were paraffin embedded, after fixation in fixative solution consisting of: formaldehyde $20 \%$, absolute alcohol $70 \%$, glacial acetic acidL10 \%. Sections were made at $4-5 \mu \mathrm{m}$, stained with hematoxylin/ eosin and were examined under light-microscope-(DIALUX $20 \mathrm{~EB})$.

\section{Statistical analysis}

The parametric data were expressed as the mean- \pm SD for the 07 rats in each group. Statistix 8.1 software was used for statistical analysis. After estimating the normality test of all the groups for various parameters the data was analyzed for one way analysis of variance to compute the differences between groups. Post hoc testing was carried out for inter-group comparisons using the least significant difference (LSD) test at $P>0.01$.

\section{Results}

Qualitative phytochemical analysis

Table 1 illustrated the phytochemical scrutiny of crude extract and its various fractions. Qualitative analysis ensured the presence of alkaloids, coumarins, tannins, saponins, flavonoids, phenols, betacyanins, terpenoids and anthraquinones in ANM. Terpenoids and anthraquinones were present in $\mathrm{ANH}$. The ANC constituted the various chemicals classes except the alkaloids and betacyanins. Tannins, saponins and betacyanins did not make their presence in ANE. The ANA contained all the chemical classes except the anthraquinones and betacyanins.

\section{Plant yield, total phenolics and flavonoid content}

The percentage yield of methanol extract and its various fractions are depicted in Table 2. The extraction yield of ANM was $86 \mathrm{~g}$ whereas the yield of its fractions; $\mathrm{ANH}$, ANC, ANE and ANA was found to be 7, 24, 21 and $33 \mathrm{~g}$ respectively. The equivalents of TPC and TFC were calculated on the basis of regression lines for gallic acids $(y=$ $\left.0.0103 \mathrm{x}+0.1875 ; R^{2}=0.9978\right)$ and rutin $(\mathrm{y}=0.00028 \mathrm{x}+$ 0.497; $R^{2}=0.998$ ) (Table 2). The highest TPC was found in ANM (631.5 $\pm 1.7 \mathrm{mg} \mathrm{GAE} / \mathrm{g}$ extract) followed by ANE $(607 \pm 1.97 \mathrm{mg} \mathrm{GAE} / \mathrm{g}$ extract), ANA $(591.2 \pm 1.3 \mathrm{mg}$ GAE/g extract), ANC (527 $\pm 3.1 \mathrm{mg} \mathrm{GAE} / \mathrm{g}$ extract). The TFC was found to be maximum in case of ANM (221.5 \pm 
Table 1 Phytochemical analysis of A. nitida bark methanol extract and derived fractions

\begin{tabular}{llllll}
\hline Compound class & \multicolumn{6}{l}{ Extract/Fraction } \\
\cline { 2 - 6 } & ANM & ANH & ANC & ANE & ANA \\
\hline Alkaloids & + & - & - & + & + \\
Anthraquinones & + & + & + & + & - \\
Tannins & + & - & + & - & + \\
Terpenoids & + & + & + & + & + \\
Saponins & + & - & + & - & + \\
Betacyanin & + & - & - & - & - \\
Coumarins & + & - & + & + & + \\
Flavonoids & + & - & + & + & + \\
Phenols & + & - & + & + & + \\
\hline
\end{tabular}

(+) present, (-) absent

ANM A. nitida methanol extract, ANH A. nitida n-hexane fraction, ANC A. nitida chloroform fraction, ANE A. nitida ethyl acetate fraction, ANA A. nitida aqueous fraction

$2.5 \mathrm{mg} \mathrm{RE} / \mathrm{g}$ extract) followed by ANE $(211.2 \pm 2.4 \mathrm{mg}$ $\mathrm{RE} / \mathrm{g}$ extract), ANA (114.8 $\pm 1.8 \mathrm{mg} \mathrm{RE} / \mathrm{g}$ extract), ANC (98.6 $\pm 1.61 \mathrm{mg} \mathrm{RE} / \mathrm{g}$ extract) (Table 2$)$.

\section{HPLC-DAD analysis of $A$. nitida stem bark}

Reverse phase HPLC analysis was carried out for quantitative estimation of highly potent known antioxidant compounds in our extracts/fractions. In this analysis absorption spectrum and retention times of extracts were compared with reference standards (rutin, catechins, gallic acid, caffeic acid, apigenin, kaempferol, quercetin and myricetin). Results are summarized in Table 3 and a representative chromatogram of ANM and ANA is shown in Fig. 1. From HPLC-DAD profiling of extracts it was observed that the ANA contains gallic acid $(550 \mu \mathrm{g} / \mathrm{g})$, rutin $(1659 \mu \mathrm{g} / \mathrm{g})$ and catechin $(2326 \mu \mathrm{g} / \mathrm{g})$, while ANM contains gallic acid $(234 \mu \mathrm{g} / \mathrm{g})$, rutin $(203 \mu \mathrm{g} / \mathrm{g})$ and catechin $(233 \mu \mathrm{g} / \mathrm{g})$ and ANE contained only the $270 \mu \mathrm{g} / \mathrm{g}$ of gallic acid.

\section{In vitro antioxidant assessment DPPH radical scavenging activity}

The scavenging capacity of ANM and its fractions against DPPH are illustrated in Table 4. The quality of antioxidants in the extract and fractions was calculated by the $\mathrm{IC}_{50}$ value, low $\mathrm{IC}_{50}$ indicates strong antioxidant activity. DPPH radical scavenging effect of various fractions of crude extract was compared with the same doses of ascorbic acid and the outcomes are depicted in Fig. 2a. Minimum $\mathrm{IC}_{50}$ values were depicted by $\mathrm{ANM}$ $(32.0 \pm 1.8 \mathrm{~d} \mu \mathrm{g} / \mathrm{ml})$ followed by $\operatorname{ANE}(39.5 \pm 2.1 \mathrm{I} \mu \mathrm{g} / \mathrm{ml})$ and ANA $(43.7 \pm 2.9 \mu \mathrm{g} / \mathrm{ml})$ while ANC and ANH showed the higher $\mathrm{IC}_{50}$ values of $(633.8 \pm 3.9 \mu \mathrm{g} / \mathrm{ml})$ and $(951.5 \pm 4.3 \mu \mathrm{g} / \mathrm{ml})$ respectively. Overall order of $\mathrm{IC}_{50}$ of $\mathrm{ANM}<\mathrm{ANE}<\mathrm{ANA}<\mathrm{ANC}<\mathrm{ANH}$ was observed. The $\mathrm{DPPH}$ radical scavenging activity of extract and fractions showed significant correlation with TPC $\left(R^{2}=0.86, P<\right.$ $0.05)$ and with TFC $\left(R^{2}=0.91, P<0.01\right)$ (Table 5).

\section{Hydroxyl radical $(\cdot \mathrm{OH})$ scavenging assay}

Hydroxyl radical scavenging capacity of an extract is directly linked to its antioxidant capacity. Figure $2 \mathrm{~b}$ exhibited the radical scavenging ability of plant samples in the following order; $\mathrm{ANM}<\mathrm{ANE}<\mathrm{ANA}<\mathrm{ANC}<\mathrm{ANH}$. Lowest $\mathrm{IC}_{50}$ values were recorded for crude extract $(97.5 \pm$ $2.9 \mu \mathrm{g} / \mathrm{ml})$ followed by ANE $(102.7 \pm 3.3 \mathrm{~L} \mu \mathrm{g} / \mathrm{ml})$ and ANA $(173.4 \pm 2.0 \mu \mathrm{g} / \mathrm{ml})$ while ANC and ANH showed the higher $\mathrm{IC}_{50}$ values of $(812.5 \pm 2.9 \mathrm{~b} \mu \mathrm{g} / \mathrm{ml})$ and $(932.5 \pm$ $3.3 \mu \mathrm{g} / \mathrm{ml}$ ) correspondingly. $\mathrm{IC}_{50}$ values of ANA, ANC and ANH were remarkably higher from rutin (83.3 \pm $4.2 \mu \mathrm{g} / \mathrm{ml}$ ). Significant correlation of $\mathrm{IC}_{50}$ values of hydroxyl radical scavenging was calculated for TPC $\left(\mathrm{R}^{2}=0.841, P<0.05\right)$ as well as for TFC $\left(R^{2}=0.753\right.$, $P<0.05$ ) (Table 4).

\section{Nitric oxide ( $\mathrm{NO}^{-}$) scavenging assay}

Lowest $\mathrm{IC}_{50}$ value of $(84.6 \pm 3.7 \mu \mathrm{g} / \mathrm{ml})$ was depicted by ANA comparative to standard ascorbic acid $(56.9 \pm$ $2.5 \mu \mathrm{g} / \mathrm{ml}) . \mathrm{IC}_{50}$ values of other extract/fractions were $(151.8 \pm 4.0 \mu \mathrm{g} / \mathrm{ml}),(153.6 \pm 4.0 \mu \mathrm{g} / \mathrm{ml}),(414.9 \pm 2.8 \mu \mathrm{g} /$

Table 2 Estimation of plant extraction yield, total phenolics, flavonoids, antioxidant capacity and reducing power of Alnus nitida bark

\begin{tabular}{llcccc}
\hline Sample & Yield $(\mathrm{g})^{*}$ & $\begin{array}{l}\text { Total phenolic contents } \\
\text { expressed as gallic acid } \\
\text { equivalents (mg/g of extract) }\end{array}$ & $\begin{array}{l}\text { Total flavonoid contents } \\
\text { expressed as rutin equivalents } \\
\text { (mg/g of extract) }\end{array}$ & $\begin{array}{l}\text { Total antioxidant capacity } \\
\text { expressed as ascorbic acid } \\
\text { equivalents (mg/g of extract) }\end{array}$ & $\begin{array}{l}\text { Total reducing power expressed } \\
\text { as ascorbic acid equivalents } \\
\text { (mg/g of extract) }\end{array}$ \\
\hline ANM & 86 & $631.5 \pm 1.7$ & $221.5 \pm 2.5$ & $32.6 \pm 1.2^{\mathrm{a}}$ & $125.5 \pm 5.0^{\mathrm{a}, \mathrm{b}}$ \\
$\mathrm{ANH}$ & 7 & 0.00 & 0.00 & $3.5 \pm 0.5^{\mathrm{c}}$ & $36.0 \pm 2.6^{\mathrm{d}}$ \\
$\mathrm{ANC}$ & 24 & $527 \pm 3.1$ & $98.6 \pm 1.61$ & $7.6 \pm 0.9^{\mathrm{c}}$ & $45.5 \pm 3.3^{\mathrm{d}}$ \\
ANE & 21 & $607 \pm 1.97$ & $211.2 \pm 2.4$ & $19.0 \pm 0.6^{\mathrm{b}}$ & $113.1 \pm 2.7^{\mathrm{b}, \mathrm{c}}$ \\
ANA & 33 & $591.2 \pm 1.3$ & $114.8 \pm 1.8$ & $16.5 \pm 1.1^{\mathrm{b}}$ & $102.0 \pm 3.3^{\mathrm{c}}$ \\
\hline
\end{tabular}

Values are presented as mean \pm SD $(n=3)$. Means with different superscript ${ }^{(\mathrm{a}-\mathrm{f})}$ letters in column are significantly $(P<0.01)$ different from each other. * Yield of ANM is based on the dry powder; the yield of its fractions is based on the yield of ANM

ANM A. nitida methanol extract, ANH A. nitida n-hexane fraction, ANC A. nitida chloroform fraction, ANE A. nitida ethyl acetate fraction, ANA A. nitida aqueous fraction 
Table 3 HPLC-DAD profile of A. nitida bark methanol extract, ANE and ANA

\begin{tabular}{llllllll}
\hline Extract & \multicolumn{7}{c}{ Polyphenolics $(\mu \mathrm{g} / \mathrm{g}$ of extract) } \\
\cline { 2 - 8 } & Rutin & Gallic acid & Catechin & Caffeic acid & Apigenin & Kaempferol & Quercetin \\
\hline ANM & 203 & 234 & 233 & - & - & - & - \\
ANE & - & 270 & - & - & - & - & - \\
ANA & 1659 & 550 & 2326 & - & - & - & - \\
\hline
\end{tabular}

ANM A. nitida methanol extract, ANH A. nitida n-hexane fraction, ANC A. nitida chloroform fraction, ANE A. nitida ethyl acetate fraction, ANA A. nitida aqueous fraction

$\mathrm{ml})$ and $(465.5 \pm 2.8 \mu \mathrm{g} / \mathrm{ml})$ for ANE, ANM, ANC and $\mathrm{ANH}$ respectively. Figure $2 \mathrm{c}$ illustrated the radical scavenging activity of different plant samples relative to standard ascorbic acid. $\mathrm{IC}_{50}$ values obtained for nitric oxide scavenging assay exhibited a significant correlation with TPC $\left(R^{2}=0.77, P<0.05\right)$ and non-significant correlation with TFC $\left(R^{2}=0.55, P>0.05\right)$ (Table 4$)$.

\section{Inhibition of $\beta$-carotene oxidation}

The best results for inhibition of $\beta$-carotene oxidation was depicted by ANE and ANA with lowest $\mathrm{IC}_{50}$ values of $(41.4 \pm 1.9 \mu \mathrm{g} / \mathrm{ml})$ and $(54.7 \pm 4.4 \mu \mathrm{g} / \mathrm{ml})$ than that of standard catechin $(90.2 \pm 2.3 \mu \mathrm{g} / \mathrm{ml})$. ANM, ANC and ANH showed the $\mathrm{IC}_{50}$ values of $(103.6 \pm 4.2 \mu \mathrm{g} / \mathrm{ml})$, $(726.2 \pm 4.7 \mu \mathrm{g} / \mathrm{ml})$ and $(858.9 \pm 3.8 \mu \mathrm{g} / \mathrm{ml})$ respectively.

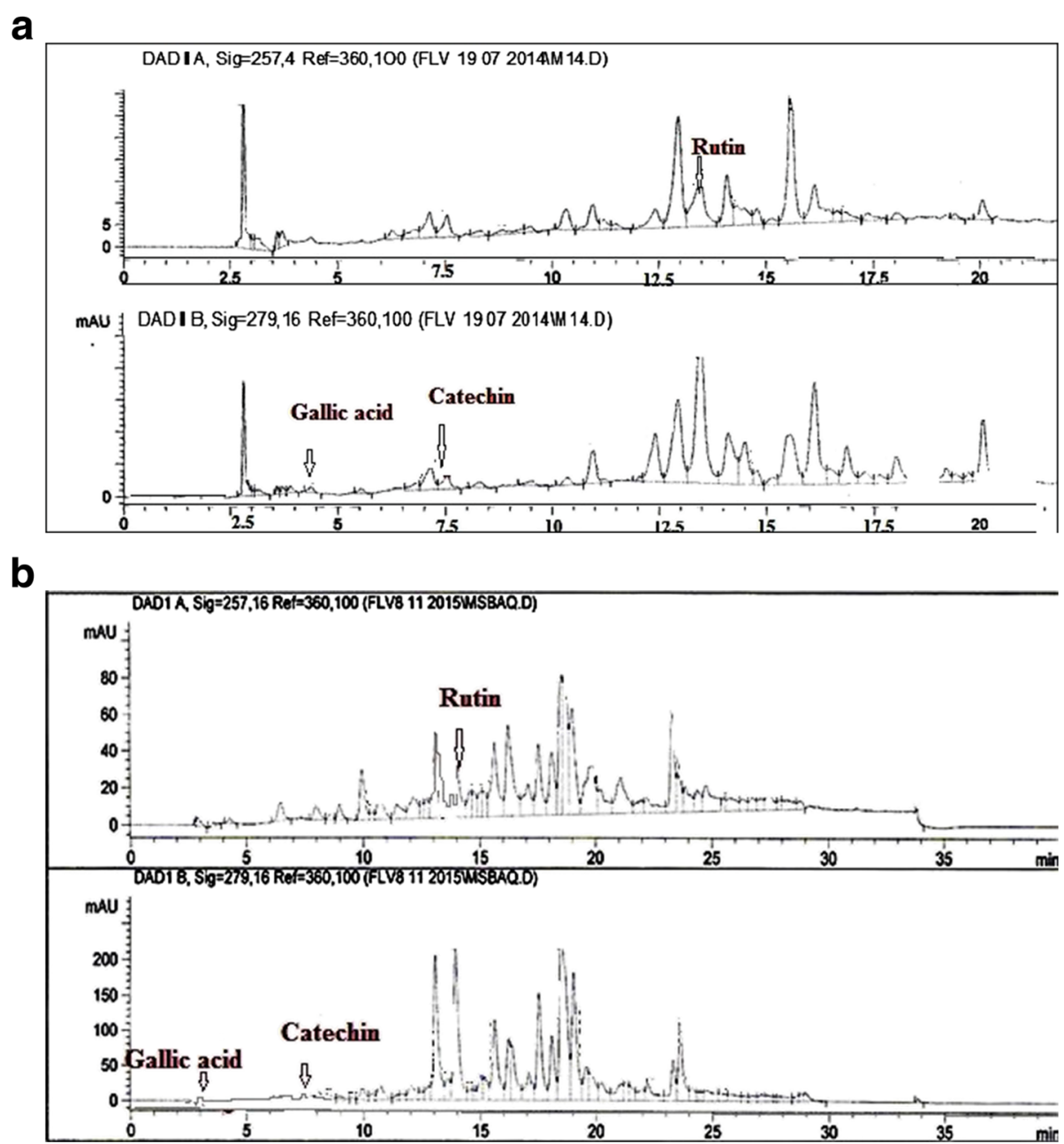

Fig. 1 HPLC-DAD chromatogram of ANM (a) and ANA (b) at different wavelengths Signal 1: 257 $\lambda$, Signal 2:279 $\lambda$. Conditions: Mobile Phase A-ACN: MEOH: $\mathrm{H}_{2} \mathrm{O}$ : AA:: 5:10:85:1, Mobile phase B-ACN: MEOH: AA:: 40:60:1, Injection volume $20 \mu \mathrm{L}$, Flow rate $1 \mathrm{ml} / \mathrm{min}$, Agilent RP-C8 
Table $4 I_{50}$ values of different antioxidant activities of ANM and its fractions

\begin{tabular}{|c|c|c|c|c|c|}
\hline \multirow[b]{2}{*}{ Sample } & \multicolumn{4}{|c|}{$\mid C_{50}(\mu \mathrm{g} / \mathrm{ml})$} & \multirow[b]{2}{*}{$\begin{array}{l}\text { Iron chelating } \\
\text { assay }\end{array}$} \\
\hline & DPPH scavenging & Hydroxyl scavenging & $\begin{array}{l}\text { Nitric oxide } \\
\text { scavenging activity }\end{array}$ & $\begin{array}{l}\beta \text {-carotene bleaching } \\
\text { scavenging activity }\end{array}$ & \\
\hline$\overline{\text { ANM }}$ & $32.0 \pm 1.8^{d}$ & $97.5 \pm 2.9^{d}$ & $153.6 \pm 4.0^{c}$ & $103.6 \pm 4.2^{c}$ & $130.5 \pm 4.1^{c}$ \\
\hline ANH & $951.5 \pm 4.3^{\mathrm{a}}$ & $932.5 \pm 3.3^{\mathrm{a}}$ & $465.5 \pm 2.8^{\mathrm{a}}$ & $858.9 \pm 3.8^{\mathrm{a}}$ & $430.2 \pm 3.9^{\mathrm{a}}$ \\
\hline ANC & $633.8 \pm 3.9^{b}$ & $812.5 \pm 2.9^{b}$ & $414.9 \pm 2.8^{b}$ & $726.2 \pm 4.7^{b}$ & $347.9 \pm 2.2^{b}$ \\
\hline ANE & $39.5 \pm 2.1^{c, d}$ & $102.7 \pm 3.3^{d}$ & $151.8 \pm 3.1^{c}$ & $41.4 \pm 1.9^{f}$ & $130.1 \pm 0.8^{c}$ \\
\hline ANA & $43.7 \pm 2.9^{c}$ & $173.4 \pm 2.0^{c}$ & $84.6 \pm 3.7^{d}$ & $54.7 \pm 4.4^{\mathrm{e}}$ & $76.8 \pm 4.5^{d}$ \\
\hline Rutin & - & $83.3 \pm 4.2^{\mathrm{e}}$ & - & - & - \\
\hline Ascorbic acid & $11.9 \pm 0.5^{\mathrm{e}}$ & - & $56.9 \pm 2.5^{\mathrm{e}}$ & - & - \\
\hline EDTA & - & - & - & - & $56.0 \pm 1.7^{e}$ \\
\hline Catechin & - & - & - & $90.2 \pm 2.3^{d}$ & - \\
\hline
\end{tabular}

Values are presented as mean \pm SD $(n=3)$. Means with different superscript ${ }^{(a-f)}$ letters in the rows are significantly $(P<0.01)$ different from each other ANM A. nitida methanol extract, ANH A. nitida n-hexane fraction, ANC A. nitida chloroform fraction, ANE A. nitida ethyl acetate fraction, ANA A. nitida aqueous fraction

Inhibition of $\beta$-carotene oxidation of ANM and its fractions at different concentrations are represented in Fig. 2d. The assay showed significant correlation of $\mathrm{IC}_{50}$ with both TPC $\left(R^{2}=0.82, P<0.05\right)$-and TFC $\left(R^{2}=0.68\right.$, $P<0.05)$ (Table 4).

\section{Iron chelating activity}

All the extract/fractions had high levels of ferrous ion chelating activity relative to standard EDTA $(56.0 \pm 1.7 \mu \mathrm{g} /$ $\mathrm{ml})$. Figure $2 \mathrm{e}$ indicated that the iron chelating activity of plant samples can be ranked as ANA, ANE, ANM, ANC and $\mathrm{ANH}$. The lower $\mathrm{IC}_{50}$ values were recorded for ANA $(76.8 \pm 4.5 \mu \mathrm{g} / \mathrm{ml})$, ANE $(130.1 \pm 0.8 \mu \mathrm{g} / \mathrm{ml})$ and ANM $(130.5 \pm 0.8 \mu \mathrm{g} / \mathrm{ml})$. TPC and TFC were significantly correlated $\left(R^{2}=0.833, P<0.05\right)$-and $\left(R^{2}=0.85, P<0.05\right)$ with reducing power respectively (Table 4 ).

\section{Reducing power assay}

Crude extract (ANM) showed the highest reducing power with $125.5 \pm 5.0 \mathrm{mg}$ ascorbic acid equivalent/g
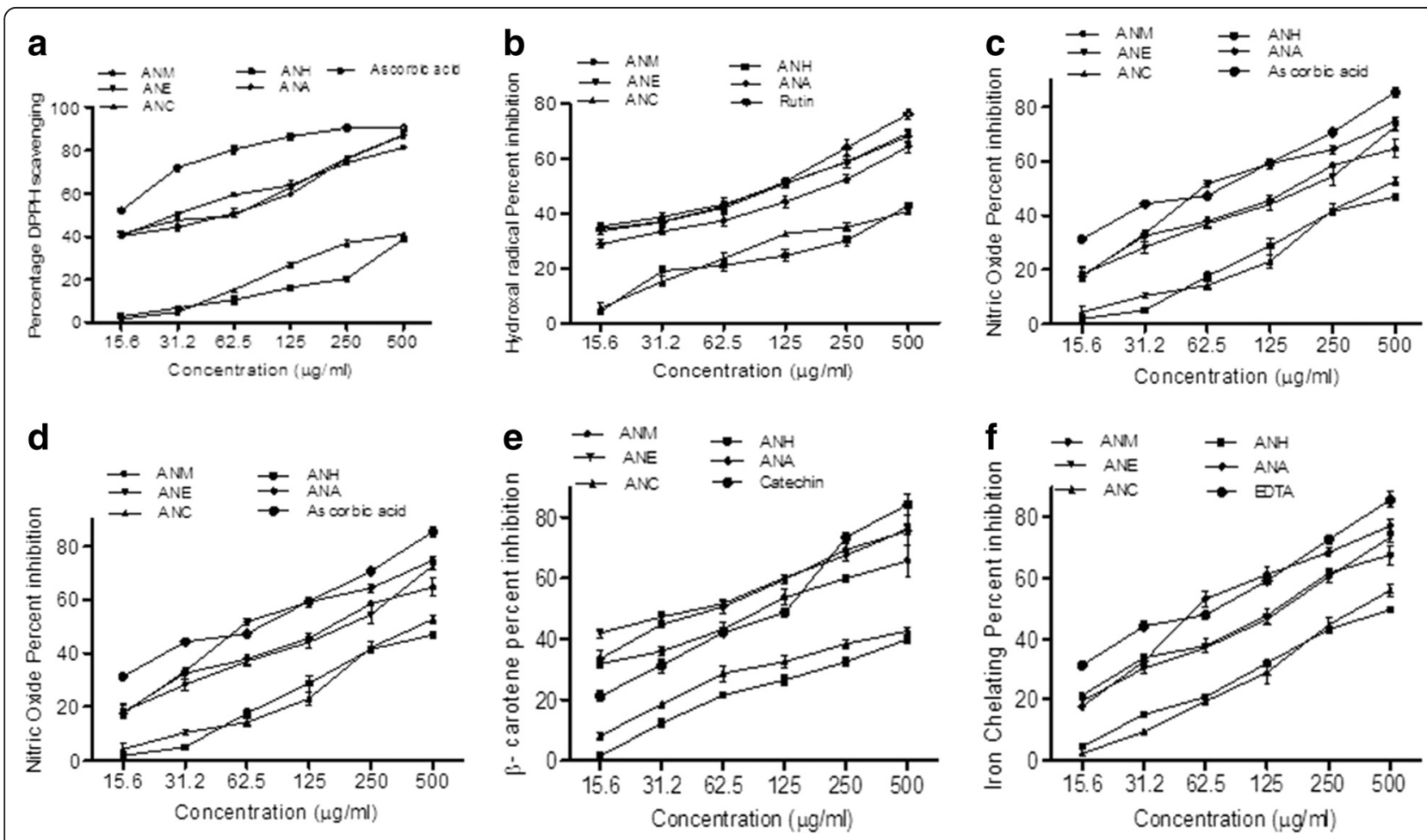

Fig. 2 Effect of different concentrations of MBM and its fractions on various in vitro antioxidant assays 
Table 5 Correlation of $\mathrm{IC}_{50}$ values of different antioxidant activities with total phenolic and total flavonoid contents

\begin{tabular}{lll}
\hline Activity & \multicolumn{2}{l}{ Correlation $\mathrm{R}^{2}$} \\
\cline { 2 - 3 } & TFC & TPC \\
\hline DPPH scavenging activity & $0.91^{* *}$ & $0.86^{*}$ \\
Nitric oxide scavenging activity & 0.55 & $0.77^{*}$ \\
Hydroxyl radical scavenging activity & $0.75^{*}$ & $0.84^{*}$ \\
$\beta$-carotene bleaching scavenging activity & $0.68^{*}$ & $0.82^{*}$ \\
Iron chelating assay & $0.85^{*}$ & $0.83^{*}$ \\
Total antioxidant activity & $0.79^{*}$ & $0.74^{*}$ \\
Total reducing power Assay & $0.80^{*}$ & $0.83^{*}$ \\
\hline
\end{tabular}

TFC total flavonoid content, TPC total phenolic content Column with different superscripts are significantly different ${ }^{*},{ }^{* *}$, indicate $P<0.05, P<0.01$

followed by ANE (113.1 $\pm 2.7 \mathrm{mg}$ ascorbic acid equivalents/ g sample), ANA (102.0 mg ascorbic acid equivalents/g sample), ANC (45.5 $\pm 3.3 \mathrm{mg}$ ascorbic acid equivalents/g sample) and ANH (36.0 $\pm 2.6 \mathrm{mg}$ ascorbic acid equivalents/g sample). There was recorded a significant correlation between the reducing power and with both TPC $\left(R^{2}=0.83\right.$, $\mathrm{P}<0.05)$ and TFC $\left(R^{2}=0.80, \mathrm{P}<0.05\right)$ shown in Table 2.

\section{Total antioxidant capacity (phosphomolybdenum assay)}

Total antioxidant capacity of various extracts was estimated by phosphomolybdate method and expressed as equivalents of ascorbic acid-(mg/g of extract). Total antioxidant capacity was found to decrease in the order, ANM $>$ ANE $>$ ANA $>$ ANC $>$ ANH. The assay showed significant correlation with TPC $\left(R^{2}=10.74, P<0.05\right)$ and TFC $\left(R^{2}=0.79, P<\mathrm{i} 0.05\right)$ as shown in Table 2 .

\section{Estimation of acute toxicity}

The plant crude methanol extract (ANM) and its derived fractions; ANH, ANC, ANE and ANA were found safe at all tested doses (up to $4000 \mathrm{mg} / \mathrm{kg}$ ) and did not show any noxious symptom in rats like sedation, convulsions, diarrhea and irritation. During the two week assessment, no mortality was found.

\section{Assessment of biochemical serum markers}

The serological concentrations of AST, ALP, ALT and bilirubin are extremely vulnerable to oxidative stress in liver tissues as depicted in Table 6. Chronic $\mathrm{CCl}_{4}$ treatment remarkably $(P<0.01)$ boosted the concentrations of serum marker enzymes of liver which was attenuated considerably $(P<0.01)$ by oral administration of ANM. However, ANM at 200 and $400 \mathrm{mg} / \mathrm{kg}$ alone exhibited the serum enzyme concentration near to that of control group.
Table 6 Effect of different treatments of ANM on liver serum markers profile

\begin{tabular}{|c|c|c|c|c|}
\hline Group & $\mathrm{ALT}(\mathrm{U} / \mathrm{l})$ & AST (U/l) & ALP $(U / I)$ & Bilirubin \\
\hline Control & $45.0 \pm 1.56^{\mathrm{e}}$ & $40.3 \pm 1.53^{e}$ & $63.7 \pm 1.10^{d}$ & $0.59 \pm 0.02^{\mathrm{d}, \mathrm{e}}$ \\
\hline $\begin{array}{l}\text { Vehicle } \\
\text { control }\end{array}$ & $40.8 \pm 1.18^{e}$ & $39.4 \pm 1.18^{\mathrm{e}}$ & $60.4 \pm 1.13^{d}$ & $0.61 \pm 0.02^{\mathrm{d}, \mathrm{e}}$ \\
\hline $\begin{array}{l}\mathrm{CCl}_{4} \\
(1 \mathrm{ml} / \mathrm{kg})\end{array}$ & $490.4 \pm 5.19^{a}$ & $320.9 \pm 3.68^{a}$ & $298.3 \pm 3.29^{a}$ & $1.97 \pm 0.01^{c}$ \\
\hline $\begin{array}{l}\text { Silymarin + } \\
\mathrm{CCl}_{4}\end{array}$ & $96.7 \pm 2.47^{d}$ & $96.9 \pm 2.31^{d}$ & $108.2 \pm 3.98^{c}$ & $0.73 \pm 0.01^{c}$ \\
\hline $\begin{array}{l}\text { ANM } \\
(200 \mathrm{mg} / \mathrm{kg}) \\
+\mathrm{CCl}_{4}\end{array}$ & $137.2 \pm 2.13^{b}$ & $166.8 \pm 2.06^{b}$ & $196.7 \pm 3.68^{b}$ & $1.02 \pm 0.10^{b}$ \\
\hline $\begin{array}{l}\text { ANM } \\
(400 \mathrm{mg} / \mathrm{kg}) \\
+\mathrm{CCl}_{4}\end{array}$ & $101.4 \pm 1.74^{c}$ & $121.4 \pm 2.74^{c}$ & $168.6 \pm 2.61^{c}$ & $0.66 \pm 0.08^{c, d}$ \\
\hline $\begin{array}{l}\text { ANM } \\
(200 \mathrm{mg} / \mathrm{kg})\end{array}$ & $52.0 \pm 3.99^{c, d}$ & $51.7 \pm 2.81^{d}$ & $73.9 \pm 2.75^{c}$ & $0.60 \pm 0.03^{\mathrm{d}, \mathrm{e}}$ \\
\hline $\begin{array}{l}\text { ANM } \\
(400 \mathrm{mg} / \mathrm{kg})\end{array}$ & $41.24 \pm 2.01^{e}$ & $37.2 \pm 1.01^{\mathrm{e}}$ & $62.2 \pm 2.70^{d}$ & $0.59 \pm 0.01^{\mathrm{e}}$ \\
\hline
\end{tabular}

Values expressed as means $\pm S D$. Means \pm SD with different superscript letter

(a-e) within the column indicate significant difference $(P<0.01)$

\section{Assessment of lipid profile of hepatic injury}

The protective effect of ANM on the lipid profile such as triglycerides, total cholesterol, HDL and LDL is given in Table 7. The level of triglycerides, total cholesterol, HDL and LDL markedly elevated $(P<0.01)$ in serum of rats after $\mathrm{CCl}_{4}$ administration. However, administration of ANM noticeably $(P<0.01)$ decreased the level of these serum markers of lipid profile, dose dependently.

Table 7 Effect of different treatments of ANM on lipid profile

\begin{tabular}{|c|c|c|c|c|}
\hline Group & $\begin{array}{l}\text { Triglycerides } \\
(\mathrm{mg} / \mathrm{dl})\end{array}$ & $\begin{array}{l}\text { Total } \\
\text { cholesterol } \\
(\mathrm{mg} / \mathrm{dl})\end{array}$ & $\begin{array}{l}\mathrm{HDL} \\
(\mathrm{mg} / \mathrm{dl})\end{array}$ & $\begin{array}{l}\mathrm{LDL} \\
(\mathrm{mg} / \mathrm{dl})\end{array}$ \\
\hline Control & $83.6 \pm 2.64^{e}$ & $99.4 \pm 2.22^{f}$ & $46.1 \pm 1.66^{\mathrm{e}}$ & $32.1 \pm 1.28^{\mathrm{d}, \mathrm{e}}$ \\
\hline $\begin{array}{l}\text { Vehicle } \\
\text { control }\end{array}$ & $89.5 \pm 2.19^{\mathrm{e}}$ & $90.3 \pm 2.48^{f}$ & $43.14 \pm 1.70^{\mathrm{e}}$ & $30.4 \pm 1.39^{\mathrm{e}}$ \\
\hline $\begin{array}{l}\mathrm{CCl}_{4} \\
(1 \mathrm{ml} / \mathrm{kg})\end{array}$ & $372.0 \pm 5.63^{\mathrm{a}}$ & $478.4 \pm 5.96^{\mathrm{a}}$ & $19.2 \pm 1.02^{\mathrm{a}}$ & $208.9 \pm 2.89^{\mathrm{a}}$ \\
\hline $\begin{array}{l}\text { Silymarin } \\
+\mathrm{CCl}_{4}\end{array}$ & $120.8 \pm 2.44^{d}$ & $162.0 \pm 2.26^{d}$ & $40.0 \pm 3.00^{e}$ & $43.4 \pm 1.55^{c}$ \\
\hline $\begin{array}{l}\text { ANM } \\
(200 \mathrm{mg} / \mathrm{kg}) \\
+\mathrm{CCl}_{4}\end{array}$ & $132.8 \pm 2.63^{b}$ & $187.8 \pm 2.63^{b}$ & $39.3 \pm 2.28^{c}$ & $44.1 \pm 2.02^{b}$ \\
\hline $\begin{array}{l}\text { ANM } \\
(400 \mathrm{mg} / \mathrm{kg}) \\
+\mathrm{CCl}_{4}\end{array}$ & $124.1 \pm 2.54^{c}$ & $152.1 \pm 2.54^{c}$ & $41.19 \pm 3.96^{\mathrm{d}}$ & $40.02 \pm 1.8^{b}$ \\
\hline $\begin{array}{l}\text { ANM } \\
(200 \mathrm{mg} / \mathrm{kg})\end{array}$ & $99.0 \pm 3.98^{c, d}$ & $92.3 \pm 2.98^{\mathrm{e}}$ & $43.0 \pm 2.98^{e}$ & $38.0 \pm 1.98^{c}$ \\
\hline $\begin{array}{l}\text { ANM } \\
(400 \mathrm{mg} / \mathrm{kg})\end{array}$ & $86.7 \pm 1.43^{\mathrm{e}}$ & $87.2 \pm 2.42^{f}$ & $47.4 \pm 1.15^{f}$ & $35.1 \pm 1.38^{d}$ \\
\hline
\end{tabular}

Values expressed as means \pm SD. Means \pm SD with different superscript letter (a-f) within the column indicate significant difference $(P<0.01)$ 


\section{Assessment of hepatic protein, TBARS, $\mathrm{IH}_{2} \mathrm{O}_{2}$, Initrite and GSH content}

The Table 8 showed profile of proteins, TBARS, $\mathrm{H}_{2} \mathrm{O}_{2}$ and nitrite content of different groups. Hepatic protein contents and GSH were reduced by $\mathrm{CCl}_{4}$ treatment $(P<$ $0.01)$ in comparison to the control group. Animals administered with ANM (400 mg/kg) alone showed an increase in protein contents and GSH as compared to the $\operatorname{ANM}(200 \mathrm{mg} / \mathrm{kg})+\mathrm{CCl}_{4}, \operatorname{ANM}(400 \mathrm{mg} / \mathrm{kg})+\mathrm{CCl}_{4}$ and only $\mathrm{CCl}_{4}$ group. $\mathrm{CCl}_{4}$ increased the TBARS, $\mathrm{H}_{2} \mathrm{O}_{2}$ and nitrite contents ofJliver homogenatesJas compared to control group (Table 8). Co-administration of ANM comprehensively prevented the rise in TBARS level in a concentration dependent fashion and non-significant difference was observed at higher dose in comparison to that of the control group. Level of $\mathrm{H}_{2} \mathrm{O}_{2}$ and nitrite content was dropped markedly and at the higher dose of ANM their level was statistically similar to that of the silymarin treated group. However, even at the higher dose of ANM their level was significantly higher against the control group. ANM, when treated in the absence of $\mathrm{CCl}_{4}$, non-significant alteration in the level of $\mathrm{H}_{2} \mathrm{O}_{2}$ and nitrite content was recorded.

\section{Assessment of crude ANM by antioxidant enzymes}

Antioxidant polyphenolic compounds have a crucial role in the reclamation of reactive oxygen species-(ROS) and help to sustain cellular balance. In order to characterize the protective effect of ANM, alteration in antioxidant enzyme level was evaluated after $\mathrm{CCl}_{4}$ treatment. The Table 9 demonstrates the protective effect of ANM on first phase antioxidant enzymes of liver i.e., CAT, POD and SOD. In comparison to the control group, the level of CAT, POD and SOD in liver tissue was markedly $(P<0.01)$ decreased after the $\mathrm{CCl}_{4}$ administration. ANM administration restored the level of these enzymes and at high dose it was statistically similar to that of the silymarin treated group. Oral administration of the ANM alone, illustrated non-significant difference in the activity level of these antioxidant enzymes in comparison to control values.

The protective effects of ANM on GST, GPx and GR in liver tissue are shown in Table 9. Activity level of GST, GPx and GR enzymes was markedly decreased ( $P$ $<0.01$ ) with $\mathrm{CCl}_{4}$ supplementation in liver tissue when compared to that of the control group. $\mathrm{CCl}_{4}$ toxicity was prevented noticeably with co-treatment of ANM in dose dependent manner. Concentration of GPx was found statistically similar to that of the control group at high dose of $400 \mathrm{mg} / \mathrm{kg}$ b.w. whereas concentration of GST and GR showed a significant difference. Activity level of GST, GP $\mathrm{X}_{\mathrm{X}}$ and GR at maximum dose of ANM was statistically similar to the silymarin treated group.

\section{Histopathological examination}

Effect of ANM on liver histology in different groups is illustrated in the Fig. 3. Histology of the liver tissue was performed at $40 \times$ to examine morphological alteration as a result of the $\mathrm{CCl}_{4}$ treatment and preventive role of ANM against $\mathrm{CCl}_{4}$ induced toxicity. Tissue sections were stained with Hematoxylin and Eosin ( $\mathrm{H} \& \mathrm{E})$. In Fig. 3 control group and the negative control group showed the normal architecture of the tissue. Treatment of $1 \mathrm{ml} / \mathrm{kg}$ b.w. of $30 \% \mathrm{CCl}_{4}$ on alternate days resulted in severe alteration of the histoarchitecture of hepatic tissues. The significant alterations observed in the $\mathrm{CCl}_{4}$ treated group were cellular hypertrophy, degeneration of lobular architecture, severe steatosis, congested blood vessels, necrosis, pyknosis, inflammatory cell infiltration, and septa formation. Co-treatment of ANM illustrated protection against toxicity and dose dependent histological protection was observed. At low dose of $200 \mathrm{mg} /$ kg b.w., steatosis, necrosis and inflammatory cells infiltration was prominent whereas at the maximum dose of ANM $(400 \mathrm{mg} / \mathrm{kg})$ and in silymarin treated group an appreciable magnitude of protection was exhibited.

Table 8 Effect of different treatments of $A$. nitida stem bark crude extract on liver tissue protein, TBARS, $\mathrm{H}_{2} \mathrm{O}_{2}$, nitrite and GSH content

\begin{tabular}{|c|c|c|c|c|c|}
\hline Group & $\begin{array}{l}\text { Protein } \\
\text { ( } \mu \mathrm{g} / \mathrm{mg} \text { tissue) }\end{array}$ & $\begin{array}{l}\text { TBARS } \\
(\mathrm{nM} / \mathrm{min} / \mathrm{mg})\end{array}$ & $\begin{array}{l}\mathrm{H}_{2} \mathrm{O}_{2} \\
(\mathrm{nM} / \mathrm{min} / \mathrm{mg} \text { tissue) }\end{array}$ & $\begin{array}{l}\text { Nitrite content } \\
(\mu \mathrm{M} / \mathrm{ml})\end{array}$ & $\begin{array}{l}\text { GSH } \\
(\mu \mathrm{M} / \mathrm{g} \text { tissue })\end{array}$ \\
\hline$\overline{\text { Control }}$ & $6.41 \pm 0.23^{\mathrm{a}}$ & $1.52 \pm 0.08^{d}$ & $6.38 \pm 0.15^{9}$ & $61.5 \pm 1.78^{d}$ & $47.0 \pm 2.84^{\mathrm{a}}$ \\
\hline Vehicle control & $6.14 \pm 0.20^{\mathrm{a}}$ & $1.73 \pm 0.07^{c, d}$ & $6.77 \pm 0.16^{9}$ & $64.2 \pm 2.83^{d}$ & $45.65 \pm 2.2^{\mathrm{a}}$ \\
\hline $\mathrm{CCl}_{4}(1 \mathrm{ml} / \mathrm{kg})$ & $3.98 \pm 0.16^{\mathrm{e}}$ & $5.32 \pm 0.06^{\mathrm{a}}$ & $18.3 \pm 0.26^{a}$ & $106.3 \pm 4.67^{\mathrm{a}}$ & $12.6 \pm 1.23^{d}$ \\
\hline Silymarin $+\mathrm{CCl}_{4}$ & $5.16 \pm 0.19^{b}$ & $2.11 \pm 0.08^{b}$ & $8.37 \pm 0.15^{\mathrm{e}}$ & $70.4 \pm 0.27^{c}$ & $46.7 \pm 1.77^{a}$ \\
\hline $\begin{array}{l}\operatorname{ANM}(200 \mathrm{mg} / \mathrm{kg}) \\
+\mathrm{CCl}_{4}\end{array}$ & $4.42 \pm 0.14^{d}$ & $2.11 \pm 0.06^{\mathrm{b}}$ & $12.2 \pm 0.21^{b}$ & $90.2 \pm 2.26^{b}$ & $30.74 \pm 1.95^{c}$ \\
\hline $\begin{array}{l}\text { ANM }(400 \mathrm{mg} / \mathrm{kg}) \\
+\mathrm{CCl}_{4}\end{array}$ & $5.02 \pm 0.14^{c}$ & $2.02 \pm 0.06^{b, c}$ & $11.1 \pm 0.14^{c}$ & $71.1 \pm 1.27^{c}$ & $41.3 \pm 1.68^{b}$ \\
\hline ANM $(200$ mg/kg) & $5.90 \pm 0.16^{\mathrm{b}, \mathrm{c}}$ & $1.81 \pm 0.39^{b}$ & $7.92 \pm 0.29^{d}$ & $61.9 \pm 2.75^{c}$ & $45.4 \pm 1.48^{a, b}$ \\
\hline ANM (400 mg/kg) & $6.48 \pm 0.32^{a}$ & $1.51 \pm 0.16^{d}$ & $7.50 \pm 0.29^{f}$ & $60.0 \pm 2.45^{d}$ & $49.1 \pm 1.84^{\mathrm{a}}$ \\
\hline
\end{tabular}

Values expressed as means \pm SD. Means \pm SD with different superscript letter ${ }^{(a-g)}$ within the column indicate significant difference $(P<0.01)$ 
Table 9 Effect of different treatments of A. nitida stem bark crude extract on liver tissues antioxidant enzymes

\begin{tabular}{|c|c|c|c|c|c|c|}
\hline Group & CAT (U/min) & POD (U/min) & SOD (U/mg protein) & GST (nM/min/mg protein) & GPx (nM/min/mg protein) & GR (nM/min/mg protein) \\
\hline Control & $6.68 \pm 0.10^{a}$ & $10.39 \pm 0.22^{a}$ & $5.54 \pm 0.36^{\mathrm{a}}$ & $139.8 \pm 3.22^{\mathrm{a}}$ & $92.8 \pm 2.05^{a}$ & $137.2 \pm 2.51^{\mathrm{a}}$ \\
\hline $\begin{array}{l}\text { Vehicle } \\
\text { control }\end{array}$ & $6.35 \pm 0.39^{a}$ & $10.06 \pm 0.43^{\mathrm{a}}$ & $5.05 \pm 0.62^{a}$ & $139.05 \pm 3.50^{a}$ & $93.3 \pm 1.27^{\mathrm{a}}$ & $133.1 \pm 3.51^{b}$ \\
\hline $\begin{array}{l}\mathrm{CCl}_{4} \\
(1 \mathrm{ml} / \mathrm{kg})\end{array}$ & $3.49 \pm 0.09^{e}$ & $5.82 \pm 0.12^{e}$ & $2.49 \pm 0.29^{c}$ & $53.77 \pm 1.61^{\mathrm{e}}$ & $32.9 \pm 1.79^{f}$ & $61.2 \pm 1.33^{f}$ \\
\hline $\begin{array}{l}\text { Silymarin } \\
+\mathrm{CCl}_{4}\end{array}$ & $5.29 \pm 0.11^{c}$ & $8.57 \pm 0.29^{b}$ & $4.65 \pm 0.32^{\mathrm{ab}}$ & $122.5 \pm 2.41^{\mathrm{b}}$ & $82.8 \pm 1.74^{d}$ & $114.5 \pm 2.58^{\mathrm{d}}$ \\
\hline $\begin{array}{l}\text { ANM } \\
(200 \mathrm{mg} / \mathrm{kg}) \\
+\mathrm{CCl}_{4}\end{array}$ & $4.30 \pm 0.15^{d}$ & $6.20 \pm 0.31^{d}$ & $3.67 \pm 0.27^{b}$ & $82.63 \pm 1.61^{d}$ & $62.4 \pm 1.77^{\mathrm{e}}$ & $86.0 \pm 3.05^{e}$ \\
\hline $\begin{array}{l}\text { ANM } \\
(400 \mathrm{mg} / \mathrm{kg}) \\
+\mathrm{CCl}_{4}\end{array}$ & $5.61 \pm 0.19 b^{c}$ & $7.57 \pm 0.33^{d}$ & $4.61 \pm 0.29^{a, b}$ & $103.8 \pm 2.97^{c}$ & $85.9 \pm 1.48^{\mathrm{c}, \mathrm{d}}$ & $119.19 \pm 2.5^{c}$ \\
\hline $\begin{array}{l}\text { ANM } \\
(200 \mathrm{mg} / \mathrm{kg})\end{array}$ & $6.19 \pm 0.20^{b}$ & $9.99 \pm 0.24^{c}$ & $4.84 \pm 0.36^{a, b}$ & $140.0 \pm 3.18^{b}$ & $90.9 \pm 2.82^{\mathrm{b}, \mathrm{c}}$ & $125.1 \pm 3.31^{\mathrm{b}}$ \\
\hline $\begin{array}{l}\text { ANM } \\
(400 \mathrm{mg} / \mathrm{kg})\end{array}$ & $6.53 \pm 0.28^{\mathrm{a}}$ & $10.14 \pm 0.21^{b}$ & $5.73 \pm 0.26^{a}$ & $141.3 \pm 2.77^{\mathrm{a}}$ & $91.0 \pm 0.91^{a, b}$ & $136.2 \pm 3.02^{\mathrm{a}}$ \\
\hline
\end{tabular}

\section{Discussion}

Nature has served as opulent repository of medicinal plants for thousands of years and remarkable number of modern drugs has been isolated from natural sources, markedly from plant origin [48]. In the present study, the complete antioxidant profiling of Alnus nitida stem bark was carried out in vitro and in vivo along with HPLC analysis. The preliminary phytochemical analysis of crude extract and its fractions exhibited a wide range of phytoconstituents such as alkaloids, anthraquinones, tannins, terpenoids, saponins, betacyanins, coumarins, flavonoids and phenols. Among the phytochemicals, phenolics and flavonoids have expanded a particular interest because of their wide ranging antioxidant activities. For this purpose polyphenols standards were selected on the basis of their reported medicinal properties for example; catechin and gallic acid have anticancer and antioxidant properties [49], caffeic acid exert the anticancer properties [50]. Rutin has antioxidant, antiviral, antihypertensive and antiplatelet properties [51]. In our analysis gallic acid was detected in crude extract as well as in ANE and ANA fractions. Therefore, it can be concluded that gallic acid is the chief phenolic compound donating to the antioxidant activity of the plant. Additionally, rutin and catechin were also detected in ANA which may be accountable for the increased antioxidant potential of the aqueous fraction. In our results significant positive correlation was found between TPC and TFC which also endorses the HPLC results.

Antioxidants especially phenolic and flavonoid contents have ability to scavenge free radicals such as superoxide and hydroxyl radicals [52]. To investigate the complete antioxidant profile of the $A$. nitida bark five different in vitro bioassays (scavenging of DPPH, hydroxyl and nitric oxide, inhibition of $\beta$-carotene bleaching and iron chelating) were performed. DPPH radical scavenging is considered as a milestone for assessing the antioxidant potential. In this study ANM, depicted the maximum scavenging followed by ANE and ANA which is expected due to flavonoids which usually contain the high metal chelating activity $[53,54]$. A. nitida stem bark extract was found to be a powerful scavenger of hydroxyl radicals which are responsible to react with an extensive range of molecules found in living cells [55]. So, scavenging of hydroxyl radical is considered to be a potent antioxidant. In our results, highest activity was showed by the ANM which is coherence with Batool et al. [56] who reported that ethanol extract of Zanthoxylum alatum fruit as the most active to scavenge hydroxyl radicals. Nitric oxide has a compelling role in various inflammatory processes and continuous production of this radical is directly toxic to tissues [57]. The results showed that the ANA ( $\mathrm{IC}_{50}$ $84.6 \mu \mathrm{g} / \mathrm{ml}$ ) has highest nitric oxide scavenging activity which is comparable with the ascorbic acid $\left(\mathrm{IC}_{50} 56.9 \mu \mathrm{g} /\right.$ $\mathrm{ml})$. Similar behavior of activity was observed in iron chelating assay which showed the highest activity ANA $\left(\mathrm{IC}_{50}\right.$ $76.8 \mu \mathrm{g} / \mathrm{ml}$ ) compared with EDTA $\left(\mathrm{IC}_{50} 56.0 \mu \mathrm{g} / \mathrm{ml}\right)$. As we know that $\mathrm{Fe}$ (III) reduction is an indicator of electron donating activity, which is a vital mechanism of phenolic antioxidant action [58] so further study is required to identify the main agent responsible for such strong activity in two different assays. Oxidation of linoleic acid is considered to estimate the antioxidant potency of a plant crude extract and fractions which operates an antioxidant in the reaction mixture to check the consumption of $\beta$ carotene by acting on linoleic acid free radicals [59]. The present study depicted the best $\beta$-Icarotene scavenging activity of ANE with lowest $\mathrm{IC}_{50}$ values even than that of 

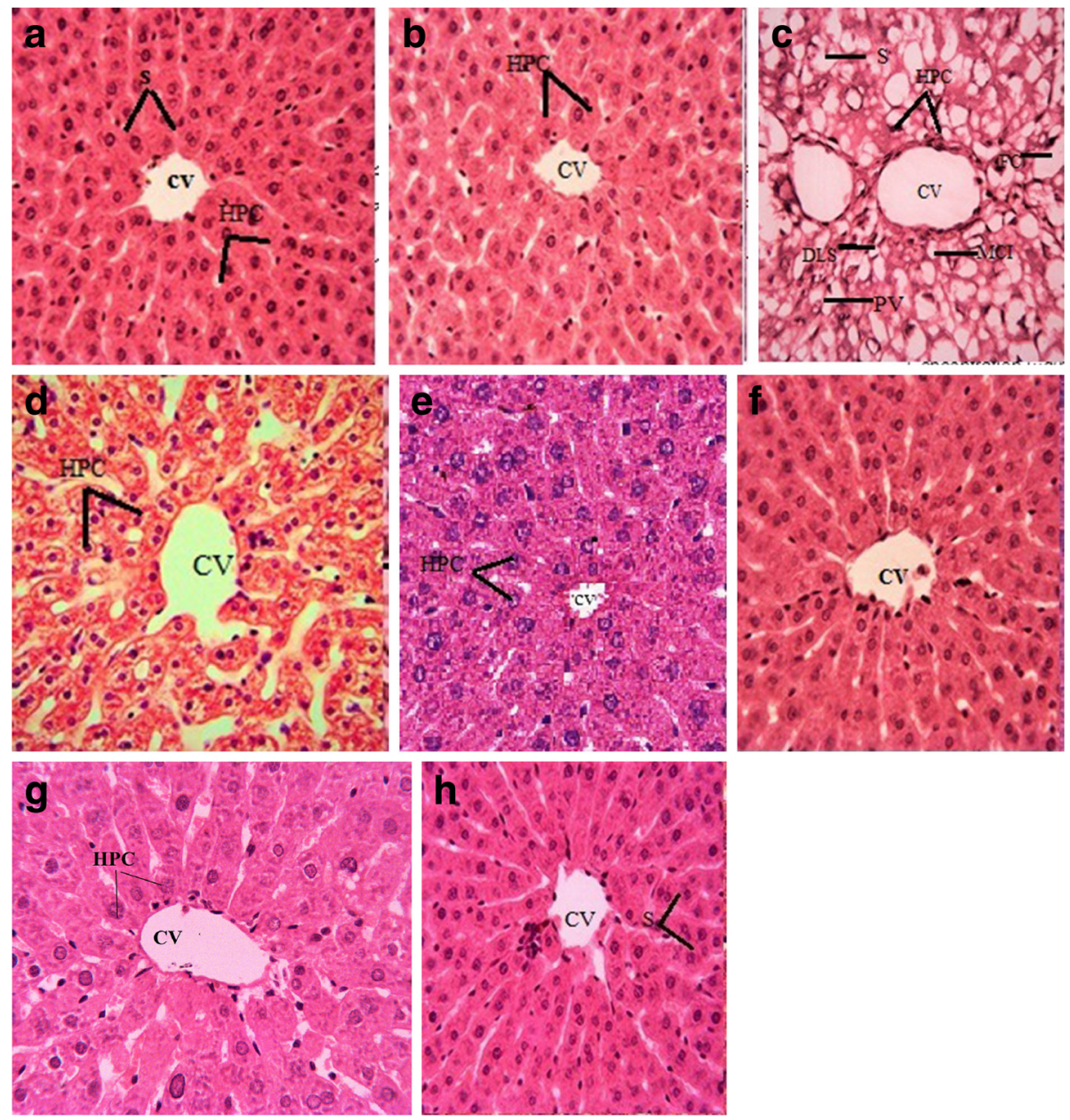

Fig. 3 Protective outcome of ANM on histology of hepatic tissues (40x magnification). a Control group b Vehicle group c CCl 1 m/kg bw, i.p., $30 \%$ in olive oil group, $\mathbf{d ~ C C l}$ + Silymarin $200 \mathrm{mg} / \mathrm{kg}$ bw group, e $\mathrm{CCl}_{4}+$ Crude extract $200 \mathrm{mg} / \mathrm{kg}$ bw group, $\mathbf{f} \mathrm{CCl}_{4}+\mathrm{Crude}$ extract $400 \mathrm{mg} / \mathrm{kg}$ bw group, $\mathbf{g}$ Crude extract 200 mg/kg bw group, h Crude extract 400 mg/kg bw group. CV; Central venule, PV; portal vein, HPC; Hepatocytes, S; Sinusoides, DLS; Degeneration of lobular shape, FC; Fatty change, and MCl; Monocyte nuclear cell infiltration

standard catechin attributed to the greater amount of phenolics and flavonoid in ethyl acetate fraction.

Phosphomolybdenum and potassium ferricynide assays are quantitative method to evaluate total antioxidant capacity and total reducing power of the plant extracts respectively. The results of both assays showed similar pattern of contents with the highest values for the ANM followed by its fractions ANE $>$ ANA $>$ ANC $>$ ANH. Our results have been supported by the previous study of Sikder et al. [60] who reported that crude methanol extract of plants exhibited highest value of antioxidant capacity and reducing power respectively. Moreover, all the antioxidant assays showed significant positive correlation with TFC and TPC except DPPH has nonsignificant correlation with TFC. Collectively, it can be proposed that he antioxidant activity of $A$. nitida may be accredited due to the existence of high content of phenolics and flavonoids which are well recognized as potential antioxidants and free radical scavengers and inhibit lipid peroxidation via the scavenging of radicals and metal chelation.

The antioxidant potential of A. nitida can also be described by the fact that the plants of this genus are endowed with terpenoids, flavonoids, diarylheptanoids, phenols, steroids and tannins. Diarylheptanoids are the dominant constituents within the genus Alnus, few of them exhibited antioxidant effects and inhibitory effects against nitric oxide and tumor necrosis factor a production [61]. Two diarylheptanoids nitidone $\mathrm{A}$ and nitidone $\mathrm{B}$ have been reported from $A$. nitida found in Northern areas of Pakistan [20]. About 400 diarylheptanoids [13] have been isolated from different species of Alnus showing various pharmacological activities; anti-inflammatory $[14,15]$, antiinfluenza [16], hepatoprotective [17]. Various isolates or the derivatives of diarylheptanoids from A. japonica showed antioxidant effects during in vitro studies $[18,19]$. 
Liver acts as a center for metabolism of proteins, lipids, carbohydrates, and it also removes unwanted metabolites. Liver secretes a biochemical called bile, which plays an important role in digestion. Based on the significant in vitro antioxidant activity, bark of $A$. nitida was evaluated for the hepato-protective effect in $\mathrm{CCl}_{4}$ challenged rats. For this purpose, rats were intra-peritoneally administrated with $\mathrm{CCl}_{4}(1 \mathrm{ml} / \mathrm{kg})$ followed by oral administration of crude extract of $A$. nitida bark with the concentration of 2001 and $400 \mathrm{mg} / \mathrm{kg}$ of rats body weight respectively. Administration of $\mathrm{CCl}_{4}$ causes hepatopathy which is indicated by elevation in AST, ALT, ALP and bilirubin in serum. Generally, $\mathrm{CCl}_{4}$ is metabolized by the liver into highly reactive metabolites which either directly or indirectly cause lipid peroxidation of the hepatocytes [62]. Different cytosolic liver marker enzymes would then leaked out from these swollen and necrotic hepatocytes in to blood circulation and clearly elevated levels are obtained that is related with the immense centrilobular necrosis, ballooning, degeneration and cellular infiltration of the liver [63]. The group administrated with $\mathrm{CCl}_{4}$ showed an increase in in serum level of triglycerides, total cholesterol, HDL and LDL (Table 7). The pathological changes in these rats indicated the potential damage in hepatic tissues prompted by $\mathrm{CCl}_{4}$ treatment (Fig. 2 and Tables 8 and 9). Our results displayed that treatment of rat with crude extract reduced the toxic effects of $\mathrm{CCl}_{4}$ and reestablished the level of above mentioned biochemical similar to untreated group which are supported by previous findings [64]. Moreover, hepatic lesions are also minimized which may be due to presence of flavonoids and phenolics in favorable amount (Fig. 2). Crude extract possibly decreased the oxidative stress by scavenging of free radicals manufactured by $\mathrm{CCl}_{4}$ with subsequent renovation in enzymatic activities and oxidative stress indicators; TBARS, $\mathrm{IH}_{2} \mathrm{O}_{2}$, nitrite, protein concentration and GSH in hepatic homogenates. These results are in coherence with Sajid et al. [65] who reported the protective activity of Artemisia scoparia against $\mathrm{CCl}_{4}$ induced oxidative stress.

Naturally, antioxidant enzymes work in a harmonized fashion to avert the oxidative stress. The metabolic role of liver in detoxification of xenobiotics consequences in the production of ROS, where SOD, CAT, POD, GSH-Px, GST and GSR play a vital role in deterrence of oxidative stress in liver samples [63]. For in vivo study, crude extract was selected because of high phenolics and flavonoids content, good antioxidant activity and noteworthy total antioxidant capacity and reducing power. In our study, activities of the antioxidant enzymes in hepatic samples were reduced by $\mathrm{CCl}_{4}$ and ameliorated by ANM. Similar protective results have been reported in cirrhotic animals [64].

The hepato-protective proficiencies of $A$. nitida obtained in this study might be also be contributed by other classes of chemicals. Buniatian et al. studied hepato-protective properties of altan (obtained on the basis of ellagitannins from the cones of black alder Alnus glutinosa) on the model of acute liver damage induced with $\mathrm{CCl}_{4}$. It was found that altan exhibits the hepato-protective activity even in a dose of $1 \mathrm{mg} / \mathrm{kg}$ which is ten-fold smaller than the dose of traditional flavonoid-based drugs [66]. Antioxidant activity of diarylheptanoids by inhibition of lipid peroxidation has been reported showing the activity of diarylheptanoids more active than $\alpha$-tocopherol [67]. The anti-hepatotoxic effects of diarylheptanoids and related analogues were assessed utilizing $\mathrm{CCl}_{4}$ and galactosamineinduced cytotoxicity in primary cultured rat hepatocytes [68]. So the diarylheptanoids might be the factor along with polyphenols contributing to the antioxidant activity of A. nitida.

Histopathological studies of ANM depicted that administration of $\mathrm{CCl}_{4}$ prompts extensive fatty change with white and yellow areas due to lipid peroxidation, congestion in blood vessels, cellular hypertrophy, necrotic foci, destruction of the lobular architecture, the development of septa and congested blood vessels with disturbed epithelium and nuclear degeneration in some areas which was significantly recovered by the crude extract (Fig. 2). The study revealed that the crude extract of $A$. nitida bark was comprised of polyphenol and terpenoids which show significant protective effect against hepatotoxicity induced by $\mathrm{CCl}_{4}$. Similar histological observation was found by various investigators [69] while assessing the protective effect of medicinal plant against $\mathrm{ICCl}_{4}$ and other drugs tempted hepatotoxicity in rats. Taken together our results showed the hepatoprotective effect of $A$. nitida bark against $\mathrm{CCl}_{4}$ induced toxicity both by in vitro and in vivo evaluation techniques.

\section{Conclusion}

Our study concluded that the hepatoprotective activity of $A$. nitida bark is likely due to the scavenging of free radicals and sustaining of endogenous antioxidant molecules. This effect appears to be facilitated by natural antioxidants in $A$. nitida bark, which remarkably diminished the oxidative stress and led to normal hepatic functions. Further exploration must be accompanied to reveal the mechanisms regarding the hepatoprotective effect of $A$. nitida bark at molecular level.

\section{Abbreviations}

ALT, alanine transaminase; ANA, Alnus nitida soluble residual aqueous fraction of ANM; ANB, Alnus nitida butanol fraction of ANM; ANC, Alnus nitida chloroform fraction of ANM; ANE, Alnus nitida ethyl acetate fraction of ANM; ANH, Alnus nitida hexane fraction of ANM; ANM, Alnus nitida methanol extract of bark; AST: aspartate transaminase; BUN, blood urea nitrogen; CAT, catalase; $\mathrm{CCl}_{4}$, carbon tetrachloride; GSH, rerduced glutathione; GSR, glutathione reductase; GST, glutathione-S-transferase; POD, peroxidase; SOD, superoxide dismutase; TBARS, thiobarbituric acid reactive substances 


\section{Acknowledgements}

MRK is intensely acknowledged for his kind supervision, expert guidance and substantial facilitations of all necessary materials and equipment. Dr. Bushra Mirza is also highly acknowledged for her assistance in HPLC.

\section{Funding}

The project was funded by the Department of Biochemistry Quaid-i-Azam University Islamabad Pakistan.

\section{Availability of data and materials}

All the data is contained in the manuscript.

\section{Authors' contributions}

MS made significant contribution to experimentation, acquisition and drafting of the manuscript. MRK has made substantial contribution to designing, analyzing and drafting of the manuscript. SAS, HI, TY and ZZ made a contribution in the experimentation and acquisition of the data. All authors read and approved the final manuscript.

\section{Authors' information}

MRK did his Diploma in Unani Medicine and Surgery (DUMS) and is a registered practitioner of the National Council for Tibb of Pakistan. He is working as Associate Professor at the Department of Biochemistry, Quaid-i-Azam University, Islamabad, Pakistan.

\section{Competing interest}

The authors declare that they have no competing interests.

\section{Consent to publish}

Not applicable.

\section{Ethics and consent to participate}

This study makes use of rats and the experimental protocol for the use of animal was approved (Bch\#0275) by the ethical board of Quaid-i-Azam University, Islamabad Pakistan.

\section{Author details}

'Department of Biochemistry, Faculty of Biological Sciences, Quaid-i-Azam University, Islamabad, Pakistan. ${ }^{2}$ Department of Biosciences, COMSATS Institute of Information Technology, Islamabad, Pakistan. ${ }^{3}$ Department of Plant Sciences, Faculty of Biological Sciences, Quaid-i-Azam University, Islamabad, Pakistan. " Department of Biochemistry and Molecular Biology, University of Gujrat, 50700 Gujrat, Pakistan.

Received: 3 March 2016 Accepted: 23 July 2016

Published online: 03 August 2016

\section{References}

1. Djeridane A, Yousfi M, Nadjemi B, Boutassouna D, Stocker P, Vidal N. Antioxidant activity of some Algerian medicinal plants extracts containing phenolic compounds. Food Chem. 2006;97(4):654-60.

2. Brewer M. Natural antioxidants: sources, compounds, mechanisms of action, and potential applications. Compr Rev Food Sci Food Saf. 2011;10(4):221-47.

3. Halliwell B, Gutteridge J. Cellular responses to oxidative stress: adaptation, damage, repair, senescence and death. In: Halliwell B, Gutteridge J, editors. Free radicals in biology and medicine. New York: Oxford University Press; 2007. p. 187-267.

4. Poljsak B, Dušan Š, Irina M. Achieving the balance between ROS and antioxidants: when to use the synthetic antioxidants. Oxid Med Cell Longev. 2013:2013:956792

5. Farmer EE, Mueller MJ. ROS-mediated lipid peroxidation and RES-activated signaling. Annu Rev Plant Biol. 2013;64:429-50.

6. Ahmad U, Sharafatullah T. Hepato-protective natural compounds. Pak J Pharmacol. 2008;25(2):59-68.

7. Naskar S, Mazumder UK, Pramanik G, Gupta M, Kumar RS, Bala A, Islam A. Evaluation of antihyperglycemic activity of Cocos nucifera Linn. on streptozotocin induced type 2 diabetic rats. J Ethnopharmacol. 2011;138(3):769-73.

8. Wu S, Yue Y, Tian H, Li Z, Li X, He W, Ding H. Carthamus red from Carthamus tinctorius $\mathrm{L}$. exerts antioxidant and hepatoprotective effect against $\mathrm{CCl}_{4}$-induced liver damage in rats via the Nrf2 pathway. J Ethnopharmacol. 2013;148(2):570-8.
9. Deng J-S, Chang Y-C, Wen C-L, Liao J-C, Hou W-C, Amagaya S, Huang S-S, Huang $\mathrm{G}-J$. Hepatoprotective effect of the ethanol extract of Vitis thunbergii on carbon tetrachloride-induced acute hepatotoxicity in rats through anti-oxidative activities. J Ethnopharmacol. 2012;142(3):795-803.

10. Maling HM, Eichelbaum FM, Saul W, Sipes IG, Brown EA, Gillette JR. Nature of the protection against carbon tetrachloride-induced hepatotoxicity produced by pretreatment with dibenamine [N-(2-chloroethyl) dibenzylamine]. Biochem Pharmacol. 1974;23(10):1479-91.

11. Nasir E, Ali Sl, Stewart RR. Flora of West Pakistan: an annotated catalogue of the vascular plants of West Pakistan and Kashmir. Karachi: Fakhri; 1972.

12. Bhatnagar S, Chopra R. The wealth of India. CSIR India. 1948;1:8.

13. Lv H, She G. Naturally occuring diarylheptanoids-A supplementary version. Rec Nat Prod. 2012;1(6):321-33.

14. Jin W, Cai XF, Na M, Lee JJ, Bae K. Diarylheptanoids from Alnus hirsuta inhibit the NF-kB activation and NO and TNF-a production. Biol Pharm Bull. 2007;30:810-3.

15. Lee M-W, Kim J-H, Jeong D-W, Ahn K-H, Toh S-H, Surh Y-J. Inhibition of cyclooxygenase-2 expression by diarylheptanoids from the bark of Alnus hirsuta var. sibirica. Biol Pharm Bull. 2000;23:517-8.

16. Tung NH, Kwon H-J, Kim J-H, Ra JC, Ding Y, Kim JA, Kim YH. Anti-influenza diarylheptanoids from the bark of Alnus japonica. Bioorg Med Chem Lett. 2010;20:1000-3.

17. Park D, Kim HJ, Jung SY, Yook CS, Jin C, Lee YS. A new diarylheptanoid glycoside from the stem bark of Alnus hirsuta and protective effects of diarylheptanoid derivatives in human HepG2 cells. Chem Pharm Bull. 2010;58(2):238-41.

18. Dinić J, Novaković M, Podolski-Renić A, Stojković S, Mandić B, Tešević V, Vajs $\mathrm{V}$, Isaković A, Pešić M. Antioxidative activity of diarylheptanoids from the bark of black alder (Alnus glutinosa) and their interaction with anticancer drugs. Planta Med. 2014;80(13):1088-96

19. Lee WS, Kim JR, Im KR, Cho KH, Sok DE, Jeong TS. Antioxidant effects of diarylheptanoid derivatives from Alnus japonica on human LDL oxidation. Planta Med. 2005:71:295-9.

20. Siddiqui IN, Ahmad VU, Zahoor A, Ahmed A, Khan SS, Khan A, Hassan Z Two new diaryl heptanoids from Alnus nitida. Nat Prod Commun. 2010;5(11):1787-8

21. Rokaya MB, Münzbergová Z, Timsina B. Ethnobotanical study of medicinal plants from the Humla district of western Nepal. J Ethnopharmacol. 2010;130(3):485-504.

22. Kim ST, Kim JD, Ahn SH, Ahn GS, Lee Yl, Jeong YS. Hepatoprotective and antioxidant effects of Alnus japonica extracts on acetami n acetaminopheninduced hepatotoxicity in rats. Phytother Res. 2004;18:971-5.

23. Nasir YJ. Flora of West Pakistan: No. 95. Betulaceae. Rawalpindi: Gordon College Pakistan; 1975.

24. Harborne JB. Phytochemical methods a guide to modern techniques of plant analysis. London, New York: Chapman and Hall Ltd; 1973. p. 49-188.

25. Trease G, Evans W. Pharmacognosy. 11th edn. Brailliar Tiridel Can. Ibadan: Macmillan publishers. Ltd; 1989. p. 10-5.

26. Kim D-O, Jeong SW, Lee CY. Antioxidant capacity of phenolic phytochemicals from various cultivars of plums. Food Chem. 2003:81(3):321-6.

27. Park Y-S, Jung S-T, Kang S-G, Heo BG, Arancibia-Avila P, Toledo F, Drzewieck J, Namiesnik J, Gorinstein S. Antioxidants and proteins in ethylene-treated kiwifruits. Food Chem. 2008;107(2):640-8.

28. Majid M, Khan MR, Shah NA, Haq IU, Farooq MA, Ullah S, Sharif A, Zahra Z Younis T, Sajid M. Studies on phytochemical, antioxidant, anti-inflammatory and analgesic activities of Euphorbia dracunculoides. BMC Complement Altern Med. 2015;15(1):1.

29. Zu Y, Li C, Fu Y, Zhao C. Simultaneous determination of catechin, rutin, quercetin kaempferol and isorhamnetin in the extract of sea buckthorn (Hippophae rhamnoides L.) leaves by RP-HPLC with DAD. J Pharm Biomed Anal. 2006;41(3):714-9.

30. Atsumi T, Iwakura I, Kashiwagi Y, Fujisawa S, Ueha T. Free radical scavenging activity in the nonenzymatic fraction of human saliva: a simple DPPH assay showing the effect of physical exercise. Antioxid Redox Signal. 1999; 1(4):537-46.

31. Leone AM, Francis PL, Rhodes P, Moncada S. A rapid and simple method for the measurement of nitrite and nitrate in plasma by high performance capillary electrophoresis. Biochem Biophys Res Commun. 1994:200(2):951-7.

32. Halliwell B, Gutteridge JMC, Aruoma Ol. The deoxyribose method: a simple "testtube" assay for determination of rate constants for reactions of hydroxyl radicals. Anal Biochem. 1987;165:215-9. 
33. Dapkevicius A, Venskutonis R, Van Beek TA, Linssen JPH. Antioxidant activity of the extracts obtained by different isolation procedures from some aromatic herbs grown in Lithuania. J Sci Food Agric. 1998;77:140-6.

34. Robinson NJ, Procter CM, Connolly EL, Guerinot ML. A ferric-chelate reductase for iron uptake from soils. Nature. 1999;397(6721):694-7.

35. Landry ML, Stanat S, Biron K, Brambilla D, Britt W, Jokela J, Chou S, Drew WL, Erice A, Gilliam B, Lurain N, Manischewitz J, Miner R, Nokta M, Reichelderfer P, Spector S, Weinberg A, Yen-Lieberman B, Crumpacker C. A standardized plaque reduction assay for determination of drug susceptibilities of cytomegalovirus clinical isolates. Antimicrob Agents Chemother. 2000:44(3):688-92.

36. Prieto $P$, Manuel $P$, Miguel A. Spectrophotometric quantitation of antioxidant capacity through the formation of a phosphomolybdenum complex: specific application to the determination of vitamin E. Anal Biochem. 1999;269(2):337-41

37. Handa S, Sharma A. Hepatoprotective activity of andrographolide from Andrographis paniculata against carbon tetrachloride. Indian J Med Res. 1990;92:276-83

38. Lowry OH, Rosebrough NJ, Farr AL, Randall RJ. Protein measurement with the Folin phenol reagent. J Biol Chem. 1951;193(1):265-75.

39. Chance B, Maehly A. [136] Assay of catalases and peroxidases. Methods Enzymol. 1955;2:764-75.

40. Kakkar P, Das B, Viswanathan P. A modified spectrophotometric assay of superoxide dismutase. Indian J Biochem Biophys. 1984;21(2):130-2.

41. Habig WH, Pabst MJ, Jakoby WB. Glutathione S-transferases the first enzymatic step in mercapturic acid formation. J Biol Chem. 1974;249(22):7130-9.

42. Carlberg I, Mannervik B. Purification and characterization of the flavoenzyme glutathione reductase from rat liver. J Biol Chem. 1975;250(14):5475-80.

43. Mohandas J, Marshall JJ, Duggin GG, Horvath JS, Tiller DJ. Differential distribution of glutathione and glutathione-related enzymes in rabbit kidney: possible implications in analgesic nephropathy. Biochem Pharmacol. 1984;33(11):1801-7.

44. Jollow D, Mitchell J, Zampaglione N, Gillette J. Bromobenzene-induced liver necrosis. Protective role of glutathione and evidence for 3, 4-bromobenzene oxide as the hepatotoxic metabolite. Pharmacology. 1974;11(3):151-69.

45. lqbal M, Wright DJ. Host resistance to insecticides can confer protection to endolarval parasitoids. Bull Entomol Res. 1996;86(06):721-3.

46. Pick E, Keisari Y. Superoxide anion and hydrogen peroxide production by chemically elicited peritoneal macrophages-induction by multiple nonphagocytic stimuli. Cell Immunol. 1981;59(2):301-18.

47. Grisham MB, Johnson GG, Lancaster J. Quantitation of nitrate and nitrite in extracellular fluids. Methods Enzymol. 1996;268(A):237-46.

48. Afsar T, Trembley JH, Salomon CE, Razak S, Khan MR, Ahmed K. Growth inhibition and apoptosis in cancer cells induced by polyphenolic compounds of Acacia hydaspica: Involvement of multiple signal transduction pathways. Sci Rep. 2016;6:23077.

49. Zhao B, Hu M. Gallic acid reduces cell viability, proliferation, invasion and angiogenesis in human cervical cancer cells. Oncol Lett. 2013;6(6):1749-55.

50. Shabbir M, Syed DN, Lall RK, Khan MR, Mukhtar H. Potent anti-proliferative, proapoptotic activity of the Maytenus royleanus extract against prostate cancer cells: evidence in in vitro and in vivo models. PLoS One. 2015:10:e0119859.

51. Yang J, Guo J, Yuan J. In vitro antioxidant properties of rutin. LWT-Food Sci Technol. 2008;41(6):1060-6.

52. Saeed N, Khan MR, Shabbir M. Antioxidant activity, total phenolic and total flavonoid contents of whole plant extracts Torilis leptophylla L. BMC Complement Altern Med. 2012;12(1):221.

53. Dorman HD, Kosar M, Kahlos K, Holm Y, Hiltunen R. Antioxidant properties and composition of aqueous extracts from Mentha species, hybrids, varieties, and cultivars. J Agric Food Chem. 2003;51(16):4563-9.

54. Shah NA, Khan MR, Naz K, Khan MA. Antioxidant potential, DNA protection, and HPLC-DAD analysis of neglected medicinal Jurinea dolomiaea roots. Biomed Res Int. 2014;2014:726241.

55. Yasuda $T$, Inaba A, Ohmori M, Endo T, Kubo S, Ohsawa K. Urinary metabolites of gallic acid in rats and their radical-scavenging effects on 1, 1 diphenyl-2-picrylhydrazyl radical. J Nat Prod. 2000;63(10):1444-6.

56. Batool F, Sabir SM, Rocha J, Shah AH, Saify ZS, Ahmed SD. Evaluation of antioxidant and free radical scavenging activities of fruit extract from Zanthoxylum alatum: a commonly used spice from Pakistan. Pak J Bot. 2010;42(6):4299-311.

57. Taylor BS, Kim Y-M, Wang Q, Shapiro RA, Billiar TR, Geller DA. Nitric oxide down-regulates hepatocyte-inducible nitric oxide synthase gene expression. Arch Surg. 1997;132(11):1177-83.
58. Yildirim A, Mavi A, Kara AA. Determination of antioxidant and antimicrobial activities of Rumex crispus L. extracts. J Agric Food Chem. 2001;49(8):4083-9.

59. Tan Z, Shahidi F. Antioxidant activity of phytosteryl phenolates in different model systems. Food Chem. 2013;138(2):1220-4.

60. Sikder AA, Rahman A, Islam R, Kaisar A, Rahman MS, Rashid MA. In vitro antioxidant, reducing power, free radical scavenging and membrane stabilizing activities of Spilanthes calva. Bangladesh Pharm J. 2010;13(1):63-7.

61. Sati SC, Sati N, Sati O. Bioactive constituents and medicinal importance of genus Alnus. Pharmacogn Rev. 2011;5:174.

62. Alkreathy HM, Khan RA, Khan MR, Sahreen $\mathrm{S}$. $\mathrm{CCl}_{4}$ induced genotoxicity and DNA oxidative damages in rats; hepatoprotective effect of Sonchus arvensis. BMC Complement Altern Med. 2014;14:452.

63. Khan RA, Khan MR, Sahreen S. Attenuation of $\mathrm{CCl}_{4}$-induced hepatic oxidative stress in rat by Launaea procumbens. Exp Toxicol Pathol. 2013;65:319-26.

64. Lin H-M, Tseng H-C, Wang C-J, Lin J-J, Lo C-W, Chou F-P. Hepatoprotective effects of Solanum nigrum Linn extract against $\mathrm{CCl}_{4}$-iduced oxidative damage in rats. Chem Biol Interact. 2008;171(3):283-93.

65. Sajid M, Khan MR, Shah NA, Ullah S, Younis T, Majid M, Ahmad B, Nigussie D. Proficiencies of Artemisia scoparia aagainst $\mathrm{CCl}_{4}$ induced DNA damages and renal toxicity in rat. BMC Complement Altern Med. 2016;16:149.

66. Buniatian N, Chikitkina V, lakovleva L. The hepatoprotective action of ellagotannins. Eksp Klin Farmakol. 1997:61:53-5.

67. Mohamad H, Lajis NH, Abas F, Ali AM, Sukari MA, Kikuzaki H, Nakatani N. Antioxidative Constituents of Etlingera e latior. J Nat Prod. 2005:68:285-8.

68. Hiroshi H, Yoshinobu K, Nobuharu K, Yasumasa H, Takayuki S, Ritsuo A, Hideji I, Fumiyuki K, Ushio S. Antihepatotoxic actions of gingerols and diarylheptanoids. J Ethnopharmacol. 1985;1985(14):31-9.

69. Abdelaziz DH, Ali SA. The protective effect of Phoenix dactylifera L. seeds against $\mathrm{CCl}_{4}$-induced hepatotoxicity in rats. J Ethnopharmacol. 2014;155(1):736-43.

\section{Submit your next manuscript to BioMed Central and we will help you at every step:}

- We accept pre-submission inquiries

- Our selector tool helps you to find the most relevant journal

- We provide round the clock customer support

- Convenient online submission

- Thorough peer review

- Inclusion in PubMed and all major indexing services

- Maximum visibility for your research

Submit your manuscript at www.biomedcentral.com/submit
) Biomed Central 